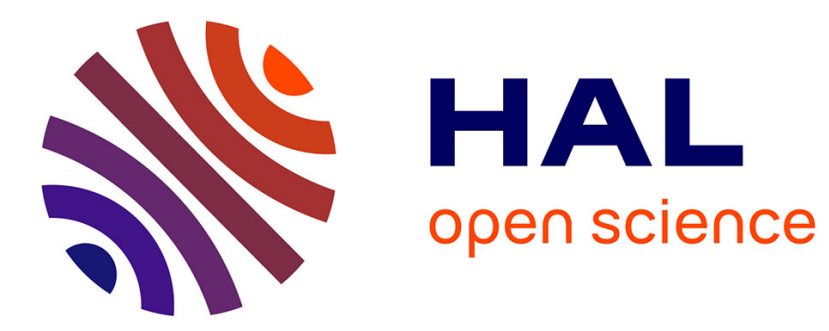

\title{
Pendrin mediates bicarbonate secretion and enhances CFTR function in airway surface epithelia
}

Dusik Kim, Junwei Huang, Arnaud Billet, Asmahan Abu-Arish, Julie Goepp, Elizabeth Matthes, Marc A Tewfik, Saul Frenkiel, John W Hanrahan

\section{- To cite this version:}

Dusik Kim, Junwei Huang, Arnaud Billet, Asmahan Abu-Arish, Julie Goepp, et al.. Pendrin mediates bicarbonate secretion and enhances CFTR function in airway surface epithelia. American Journal of Respiratory Cell and Molecular Biology, 2019, 60 (6), pp.705-716. 10.1165/rcmb.2018-0158OC . hal03145546

\author{
HAL Id: hal-03145546 \\ https://hal.science/hal-03145546
}

Submitted on 18 Feb 2021

HAL is a multi-disciplinary open access archive for the deposit and dissemination of scientific research documents, whether they are published or not. The documents may come from teaching and research institutions in France or abroad, or from public or private research centers.
L'archive ouverte pluridisciplinaire HAL, est destinée au dépôt et à la diffusion de documents scientifiques de niveau recherche, publiés ou non, émanant des établissements d'enseignement et de recherche français ou étrangers, des laboratoires publics ou privés. 


\title{
Pendrin mediates bicarbonate secretion and enhances CFTR function in airway surface epithelia
}

\author{
Dusik Kim ${ }^{1,2}$, Junwei Huang ${ }^{1,2, \pi}$, Arnaud Billet ${ }^{1,2, \pm}$, Asmahan Abu-Arish ${ }^{1,2}$, Julie \\ Goepp $^{1,2}$, Elizabeth Matthes ${ }^{1,2}$, Marc A. Tewfik ${ }^{2,3}$, Saul Frenkiel ${ }^{2,3}$ and \\ John W. Hanrahan ${ }^{1,2,4}$ \\ 1Department of Physiology, McGill University, Mclntyre Medical Sciences Building, \\ Montréal, Québec Canada H3G 1Y6 \\ ${ }^{2}$ Cystic Fibrosis Translational Research Centre, McGill University \\ ${ }^{3}$ Department of Otolaryngology-Head and Neck Surgery, McGill University Health \\ Center, Montréal, \\ ${ }^{4}$ Research Institute - McGill University Health Centre, Montréal
}

Running title: $\mathrm{HCO}_{3}{ }^{-}$secretion by airway surface epithelia

Keywords: SLC26A4, anion exchanger, ABCC7, cystic fibrosis, COPD, asthma

Author Contributions: Conception and design: D.K., J.H., A.B. and J.W.H.; data acquisition: D.K., J.H., A.B. and E.M.; analysis and interpretation: D.K., J.H., A.B., A.A., and J.W.H.; drafting of the manuscript: D.K. and J.W.H.; and revision of the manuscript for important intellectual content: D.K., J.G., M.A.T., S.F. and J.W.H.

\section{Current addresses:}

"AbbVie Bioresearch Center, AbbVie Inc., 381 Plantation St., Worcester, MA 01605 USA

‡Signalisation et Transports loniques Membranaires (STIM) - ERL 7368, Bât. B36 - Pôle Biologie Santé 1, rue Georges Bonnet TSA 51106 86073, Poitiers Cedex 9 France

\section{Correspondence and requests for reprints:}

Dusik Kim dusikkim@gmail.com or John Hanrahan john.hanrahan@mcgill.ca CFTRc, Department of Physiology, McGill University, 3655 Promenade Sir William Osler, Montréal, Québec Canada H3G 1 Y6. 


\section{ABSTRACT}

Bicarbonate facilitates mucin unpacking and bacterial killing however its transport mechanisms in the airways are not well understood. cAMP stimulates anion efflux through the CFTR (ABCC7) anion channel and this is defective in CF. The anion exchanger pendrin (SLC26A4) also mediates $\mathrm{HCO}_{3}{ }^{-}$efflux and is upregulated by proinflammatory cytokines. Here we examined pendrin and CFTR expression and their contributions to $\mathrm{HCO}_{3}{ }^{-}$secretion by human nasal and bronchial epithelia. In native tissue, both proteins were most abundant at the apical pole of ciliated surface cells with little expression in submucosal glands. In well-differentiated primary nasal and bronchial cell cultures, IL-4 dramatically increased pendrin mRNA levels and apical immunostaining. Exposure to low-Cl- apical solution caused intracellular alkalinization $\left(\Delta \mathrm{pH}_{\mathrm{i}}\right)$ that was enhanced 4-fold by IL-4 pretreatment. $\Delta \mathrm{pH}_{\mathrm{i}}$ was unaffected by DIDS or $\mathrm{CFTR}_{\mathrm{inh}}-172$ but was reduced by adenoviral shRNA targeting pendrin. Forskolin increased $\Delta \mathrm{pH}_{\mathrm{i}}$ and this stimulation was prevented by CFTR $\mathrm{inh}_{\mathrm{inh}}-172$ implicating CFTR, yet forskolin only increased $\Delta \mathrm{pH}_{\mathrm{i}}$ after pendrin expression had been induced by IL-4. The dependence of $\Delta \mathrm{pH}_{\mathrm{i}}$ on pendrin suggests there is minimal electrical coupling between $\mathrm{Cl}^{-}$and $\mathrm{HCO}_{3}{ }^{-}$fluxes and that CFTR activation increases anion exchange-mediated $\mathrm{HCO}_{3}^{-}$influx. Conversely, inducing pendrin expression increased forskolin-stimulated, $\mathrm{CFTR}_{\text {inh }}-172$-sensitive current by $\sim 2$ fold in epithelial and non-epithelial cells. We conclude that pendrin mediates most $\mathrm{HCO}_{3}{ }^{-}$ secretion across airway surface epithelium during inflammation and enhances electrogenic $\mathrm{Cl}^{-}$secretion via CFTR as described for other SLC26A transporters. 


\section{CLINICAL RELEVANCE}

Luminal pH plays a critical role in airway host defense and depends in part on bicarbonate secretion, however the mechanisms of $\mathrm{HCO}_{3}{ }^{-}$secretion are not well understood. We show here that pendrin becomes a major route for $\mathrm{HCO}_{3}{ }^{-}$secretion when its expression is upregulated by a proinflammatory cytokine and that pendrin also enhances cAMP stimulation of CFTR. Thus pendrin plays a central role in $\mathrm{HCO}_{3}{ }^{-}, \mathrm{Cl}^{-}$ and fluid secretion by inflamed airways.

\section{INTRODUCTION}

Anion secretion by airway epithelia is required for efficient mucociliary clearance of inhaled particles and pathogens from the lungs. Electrogenic $\mathrm{Cl}^{-}$secretion generates a transepithelial potential that drives paracellular sodium flow, and the resulting salt transport generates an osmotic gradient that drives fluid secretion (1). Bicarbonate is also secreted into the airway lumen and this transport is reduced in cystic fibrosis (CF) indicating an important role for CFTR (2). Despite the importance of $\mathrm{HCO}_{3}{ }^{-}$in $\mathrm{CF}$ and other respiratory diseases the mechanisms mediating apical $\mathrm{HCO}_{3}{ }^{-}$ efflux remain uncertain.

Airway epithelia express apical cAMP- and $\mathrm{Ca}^{2+}$-activated channels that are permeable to both $\mathrm{Cl}^{-}$ and $\mathrm{HCO}_{3}^{-}$(3-6). Under bi-ionic conditions, the equilibrium permeability ratio for $\mathrm{CFTR}\left(\mathrm{P}_{\mathrm{HCO}}-\right.$ $/ \mathrm{P}_{\mathrm{Cl}}$ ) is 0.14 with $\mathrm{HCO}_{3}{ }^{-}$bathing the extracellular aspect $(5,6)$ and somewhat higher $(0.25)$ when $\mathrm{HCO}_{3}{ }^{-}$is present intracellularly (5). The Calu-3 cell line expresses CFTR at high levels and generates a large forskolin-stimulated short-circuit current $\left(\mathrm{I}_{\mathrm{sc}}\right)$ that is carried exclusively by $\mathrm{HCO}_{3}{ }^{-}$(7-10). Electrogenic $\mathrm{HCO}_{3}{ }^{-}$secretion is also observed across airway epithelia ex vivo during 
cAMP stimulation. Early studies of canine trachea showed that a fraction of the cAMP-stimulated $\mathrm{I}_{\mathrm{sc}}$ is carried by $\mathrm{HCO}_{3}^{-}(11,12)$, although electroneutral $\mathrm{HCO}_{3}^{-}$secretion under particular conditions was not excluded, for example during inflammation when the expression of transporters such as pendrin is increased $(13,14)$. Pendrin mediates $\mathrm{Cl}^{-} / \mathrm{HCO}_{3}^{-}(15,16), \mathrm{Cl}^{-} /$formate $(17)$, and $\mathrm{Cl}^{-} / \mathrm{I}^{-}$(18) exchange and its expression is strongly induced by IL-4, IL-13 and IL-17A (19-24), proinflammatory cytokines that are implicated in several airway diseases (25). Pendrin levels increase in animal models of bronchial asthma and chronic obstructive pulmonary disease (COPD) and are associated with mucous cell hyperplasia and mucus accumulation $(23,26)$. Asthma and COPD symptoms are less severe in pendrin null mice and can be induced by ectopic pendrin expression, which implies a causal relationship whereby pendrin increases disease severity (23). Although $\mathrm{HCO}_{3}^{-}$transport by $\mathrm{CFTR}$ and pendrin clearly play important roles in airway pathophysiology, the interactions between these pathways and their relative contributions to $\mathrm{HCO}_{3}{ }^{-}$secretion are not well understood.

Exposing bronchial epithelial cell cultures to IL-4 increases cAMP- and $\mathrm{Ca}^{2+}$-stimulated $\mathrm{I}_{\mathrm{sc}}$ and elevates the expression of pendrin and many other transporters and channels (27). Since pendrin is an electroneutral anion exchanger, increased expression of apical CFTR and the basolateral $\mathrm{Na}^{+}, \mathrm{K}^{+}, 2 \mathrm{Cl}^{-}$cotransporter $\mathrm{NKCC} 1$ have been suggested as possible reasons for larger $\mathrm{I}_{\mathrm{sc}}$ responses to cAMP after IL-4 treatment (27). Alternatively, CFTR might be regulated by pendrin as occurs in mouse pancreatic duct (28) and with other SLC26A transporters notably SLC26A3, SLC26A6, and SLC26A9 (28-30). Conversely, CFTR can increase pendrin activity (28) through interaction of its R domain with the STAS domain of pendrin (29) although in the airways it remains unclear whether CFTR and pendrin are expressed in the same cells where they could physically interact. 
The aim of this study was to clarify the roles of pendrin and CFTR in $\mathrm{HCO}_{3}{ }^{-}$secretion by nasal and bronchial surface epithelia. We began by localizing the transporters in bronchial tissue and well-differentiated primary cultures, then studied their expression and function in well differentiated primary nasal and bronchial epithelial cell cultures.

\section{MATERIALS AND METHODS}

\section{Human airway tissue and cells}

Lung and nasal samples were obtained with informed consent following protocols approved by the Institutional Review Boards of the IRCM and McGill University (\#A08-M70-14B). Cell isolation and histological methods are detailed in SUPPLEMENTAL INFORMATION.

\section{Immunostaining pendrin and CFTR in bronchial sections and primary cultures}

Fresh tissue specimens were collected within $48 \mathrm{~h}$ of lung resection and fixed in $10 \%$ neutral buffered formalin overnight at $4{ }^{\circ} \mathrm{C}$ for paraffin embedding and sectioning. Primary cells were cultured on collagen-coated Transwell ${ }^{\mathrm{TM}}$ inserts, incubated with PBS on the apical side for 15 min at $37{ }^{\circ} \mathrm{C}$ in a $5 \% \mathrm{CO}_{2}$ incubator, and rinsed three times to reduce mucus immediately before immunostaining. (see SUPPLEMENTAL INFORMATION for details).

\section{RNA interference and qRT-PCR}

Adenovirus particles (Biofocus DPI/Galapagos, Leiden, Netherlands) were used to express shRNAs that target pendrin transcripts (see SUPPLEMENTAL INFORMATION). Pendrin shRNA reduced pendrin mRNA levels by 50\% (Supplementary Figure 1) 


\section{Intracellular pH measurement}

Intracellular $\mathrm{pH}$ was measured using an inverted fluorescence microscope (IX81, Olympus, Center Valley PA) and imaging system (Photon Technology International, Edison NJ) as described (7, 31). Cells were loaded with the ratiometric $\mathrm{pH}$-sensitive dye BCECF-AM and studied at $37{ }^{\circ} \mathrm{C}$ with independent perfusion of the apical and basolateral sides as described in the SUPPLEMENTAL INFORMATION.

\section{Short-circuit current measurements}

Snapwell ${ }^{\mathrm{TM}}$ inserts were mounted in Ussing chambers to measure $\left(\mathrm{I}_{\mathrm{sc}}\left(\mu \mathrm{A} \mathrm{cm} \mathrm{cm}^{-2}\right)\right.$. Transepithelial voltage was clamped at $0 \mathrm{mV}$ except during $2 \mathrm{~s}$ bipolar pulses to $\pm 1 \mathrm{mV}$ at $100 \mathrm{~s}$ intervals to monitor resistance. Basolateral solution contained (mmol 1-1): $115 \mathrm{NaCl}, 25 \mathrm{NaHCO}_{3}$, 1.2 $\mathrm{MgCl}_{2}, 1.2 \mathrm{CaCl}_{2}, 2.4 \mathrm{KH}_{2} \mathrm{PO}_{4}, 1.24 \mathrm{~K}_{2} \mathrm{HPO}_{4}$, and 10 D-glucose. Apical solution contained (mmol 1' ${ }^{-1}$ ): $1.2 \mathrm{NaCl}, 115 \mathrm{Na}$-gluconate, $25 \mathrm{NaHCO}_{3}, 1.2 \mathrm{MgCl}_{2}, 4 \mathrm{CaCl}_{2}, 2.4 \mathrm{KH}_{2} \mathrm{PO}_{4}, 1.24 \mathrm{~K}_{2}$ $\mathrm{HPO}_{4}$, and 10 glucose. After $\mathrm{I}_{\mathrm{sc}}$ had stabilized, amiloride was added apically to block $\mathrm{Na}^{+}$ absorption and this was followed by sequential apical additions of forskolin $(10 \mu \mathrm{M})$, CFTR inhibitor, CFTR $_{\text {inh }^{-172}}(10 \mu \mathrm{M})$ and ATP $(100 \mu \mathrm{M})$.

\section{Patch clamp}

BHK cells stably expressing wild-type CFTR were seeded on plastic coverslips at low density and transfected the following day with the expression plasmid pReceiver-M29 containing the CMV promoter to drive expression of EGFP-SLC26A4 (EGFP fused to the N-terminus of pendrin; Genecopoeia, Germantown MD). Patch-clamp experiments were performed 1-2 days after 
transfection. Whole cell $\mathrm{Cl}^{-}$currents were measured after compensating for pipette capacitance electronically in the cell-attached mode. (see SUPPLEMENTAL INFORMATION).

\section{Fluid transport}

ASL height was measured using an LSM-780 confocal microscope (Zeiss, Jena, Germany) equipped with a multiline argon laser $(488 \mathrm{~nm}, 561 \mathrm{~nm})$ after labeling the surface liquid with BCECF-dextran (see SUPPLEMENTAL INFORMATION). Secretions were collected by aspiration and measured using a micropipet as described previously (32) after 2 days exposure to basolateral $10 \mu \mathrm{M}$ forskolin and apical $10 \mu \mathrm{M}$ amiloride.

\section{Statistics}

Data are means \pm standard error of mean (s.e.m.) of $n$ observations except the histogram in Fig. 7C, which shows means \pm standard deviation (s.d.). Data sets were compared using the Student's t-test (GraphPad Prism) with $\mathrm{p}<0.05$ considered significant unless otherwise indicated.

\section{RESULTS}

\section{Pendrin co-localizes with CFTR in ciliated airway surface epithelial cells}

Bronchial tissue sections were immunostained for both CFTR and pendrin. In non-CF bronchus

(Figure 1A, top row of images), most CFTR was detected at the apical pole of ciliated cells that covered much of the airway surface (green fluorescence, epithelium outlined by white dotted lines). A similar distribution was observed using anti-pendrin antibody (Figure 1A, PDS, red). Colocalization of CFTR and pendrin is indicated by yellow in the merged images (Figure 1A). CF bronchus had barely detectable CFTR immunostaining as expected and moderately increased 
pendrin staining compared to non-CF tissue (second row of images in Figure 1A). Specificity of CFTR immunostaining in surface epithelium was further confirmed by the absence of signal when primary anti-CFTR antibody was omitted (Figure $1 \mathrm{~A}$, WO $1^{\circ}$ ). Omitting the anti-pendrin primary antibody caused a similar decrease in the pendrin signal (data not shown). CFTR and pendrin immunostaining were less prominent in submucosal gland mucus (MC) and serous (SC) cells (Figure 1B). The glands (outlined using white dotted lines in the fluorescence images) were identified as mucous cells (MC) or serous cells (SC) based on their granularity and by comparison with sections that had been stained for mucins using Alcian-blue periodic acid Schiff stain (ABPAS; data not shown). Although a diffuse signal was detected for both proteins in serous cells, it was weak and was not near the apical membrane (Figure 1B). These results indicate that pendrin is prominently expressed in surface epithelial cells in vivo but not in submucosal glands.

Pendrin expression was also examined en face in first passage primary nasal and bronchial epithelial cultures treated with vehicle $(0.1 \%$ DMSO) or IL-4 (10 ng/ml) for 2 days (Figure 1C). Immunostaining was low in non-CF nasal inferior turbinate and bronchial cells under control conditions (Figure 1C, left panels) but increased after pretreatment with IL-4 (Figure 1C, right panels). Although pendrin immunostaining varied between patients, it was usually higher in $\mathrm{CF}$ bronchial cells compared to non-CF cells and was further increased by IL-4.

$\mathrm{X}-\mathrm{Z}$ images constructed from image stacks revealed more prominent pendrin expression at the apical pole of both non-CF and CF bronchial cells after 2 days pretreatment with IL-4 (10 ng/ml) compared to vehicle (0.1\% DMSO, Figure 1D). Cellular coexpression of pendrin and CFTR in vitro was assessed using non-CF bronchial cells that had been maintained at the air-liquid interface 
for $\geq 4$ weeks and then treated with DMSO or IL-4 (10 ng/ml) for 2 days (Figure 1E). X-Y images revealed increased pendrin (red) immunostaining after IL-4 exposure and coexpression with CFTR in some cells (white arrowheads). When well-differentiated bronchial epithelial cells treated with DMSO or IL-4 were gently scraped from the culture supports, fixed and immunostained, CFTR (green) was clearly concentrated near the apical pole of the cell (Figure 1F, left panels) and its levels and distribution were not noticeably affected by IL-4 pretreatment. By contrast, pendrin immunostaining (red, center panels) was more intense after IL-4, forming a band at the apical pole (shown by the white arrowheads) that was colocalized with CFTR at the bases of cilia (yellow merged signal, bottom right panel).

\section{Pendrin mRNA expression is elevated in CF cells and further increased by IL-4}

We used qRT-PCR to quantify mRNA transcripts coding for CFTR, pendrin, and the pendrinrelated anion channel SLC26A9 (33) under the conditions used below for functional studies. In non-CF nasal and bronchial cells, CFTR mRNA levels normalized to GAPDH mRNA appeared 3- to 7-fold higher than those for pendrin under basal conditions (Figure 2A,B) and SLC26A9 transcripts were 3- to 5-fold more abundant than those for CFTR. These differences between genes are only approximate as they rely on different primer sets, nevertheless they confirm the low expression of pendrin under basal conditions. Pendrin transcript levels were much higher in $\mathrm{CF}$ than in non-CF bronchial cells (Figure 2C), consistent with the immunostaining shown in Figure 1A (native tissue) and Figure 1C (primary culture).

Exposure to IL-4 $(10 \mathrm{ng} / \mathrm{ml})$ for 2 days dramatically increased pendrin mRNA in non-CF nasal and bronchial cells (normalized to DMSO vehicle, Figure 2E,F). IL-4 also elevated pendrin 
expression in CF bronchial epithelial cells, although the relative increase (2- to 5-fold) was smaller than in non-CF cells due to the higher basal expression in CF (Fig. 2G). The Calu-3 cell line was also compared with primary surface epithelial cells (Figure 2D) and had higher levels of CFTR mRNA but low pendrin and SLC26A9 mRNA expression, consistent with previous studies (7, 10, 31). Moreover, IL-4 did not increase pendrin mRNA expression in the Calu-3 (Figure 2H) consistent with our previous studies (7). Figure 2I summarizes the relative expression of CFTR and pendrin transcripts in non-CF and CF cells in untreated (naïve) cells and after pretreatment with IL-4. All values were normalized to those for non-CF cells treated with vehicle. Consistent with immunostaining results, pendrin mRNA expression in $\mathrm{CF}$ bronchial cells was generally higher than in non-CF cells and was further increased several-fold by IL-4.

\section{Pendrin mediates $\mathrm{Cl}^{-} / \mathrm{HCO}_{3}^{-}$and $\mathrm{Cl}^{-} / \mathrm{I}^{-}$antiport and enhances forskolin-stimulated electrogenic anion transport}

We studied apical bicarbonate transport in nasal and bronchial epithelial cells by measuring the increase in intracellular $\mathrm{pH}\left(\Delta \mathrm{pH}_{\mathrm{i}}\right)$ when cells were briefly challenged with low-Cl- saline (gluconate replacement) on the apical side. $\Delta \mathrm{pH}_{\mathrm{i}}$ in nasal cells was small under basal conditions (Figure 3A) but became much larger after the cells had been pretreated with IL-4 for 2 days (Figure 3B). The rate of re-acidification upon restoring extracellular $\mathrm{Cl}^{-}\left(\mathrm{dpH}_{\mathrm{i}} / \mathrm{dt}\right.$, dashed red lines) was also increased by 3- to 4-fold, indicating faster $\mathrm{Cl}^{-} / \mathrm{HCO}_{3}{ }^{-}$antiport in IL-4-treated nasal cells $(0.029$ \pm 0.013 vs $0.113 \pm 0.004 \mathrm{pH}$ units $\min ^{-1}, \mathrm{n}=4$, Figure 3B). Iodide can be carried by pendrin (18) but not by most other anion exchangers and provides a useful tool for identifying pendrin-mediated transport (34). Selectivity was assessed as the re-acidification rate after $\Delta \mathrm{pH}_{\mathrm{i}}$ when low-Clsolution was replaced with one containing $\mathrm{I}^{-}$(Figure 3C,F). This rate was similar when apical 
gluconate was replaced with either $\mathrm{Cl}^{-}$or $\mathrm{I}^{-}(0.113 \pm 0.004$ vs $0.083 \pm 0.059 \mathrm{pH}$ units, $\mathrm{n}=4-5$, not significant $\mathrm{p}=0.37$ ) consistent with $\mathrm{HCO}_{3}^{-} / \mathrm{I}^{-}$exchange and pendrin-mediated base efflux. Similar results were obtained when non-CF bronchial epithelial cells were pretreated with vehicle for 2 days before challenge with low- $\mathrm{Cl}^{-}$solution; there was little increase in $\mathrm{pH}_{\mathrm{i}}$ irrespective of forskolin stimulation (Figure 3D). By contrast, after treatment with IL-4 for 2 days acute challenge with low- $\mathrm{Cl}^{-}$extracellular solution caused abrupt intracellular alkalinization in bronchial cells that was further enhanced by forskolin stimulation $\left(\Delta \mathrm{pH}_{\mathrm{i}}=0.046 \pm 0.065\right.$ (basal) vs $0.288 \pm 0.023 \mathrm{pH}$ units (with IL-4 and forskolin, $\mathrm{n}=4$; Figure $3 \mathrm{E}-\mathrm{G}$ ). A spontaneous decline in $\Delta \mathrm{pH}_{\mathrm{i}}$ during pulses with apical $0 \mathrm{Cl}^{-}$solution under these conditions suggests that basolateral $\mathrm{Cl}^{-}$entry may become rate-limiting for apical anion exchange during forskolin stimulation (Fig. 3E, second pulse). Taken together, these results suggest that pendrin expression induced by IL-4 increases apical $\mathrm{HCO}_{3}^{-} / \mathrm{Cl}^{-}$ antiport which is further enhanced by CFTR activation in nasal and bronchial epithelial cells.

Further evidence for the role of CFTR in apical anion exchange comes from the partial inhibition of $\Delta \mathrm{pH}_{\mathrm{i}}$ by the CFTR inhibitor $\mathrm{CFTR}_{\mathrm{inh}}-172$ (Supplementary Figure 2). Remarkably, forskolin alone did not enhance $\Delta \mathrm{pH}_{\mathrm{i}}$ in primary cells despite the presence of functional CFTR channels, in contrast to previous results in Calu-3 cells where $\Delta \mathrm{pH}_{\mathrm{i}}$ was also elicited by apical low- $\mathrm{Cl}^{-}$solution only during forskolin stimulation. This indicates that $\Delta \mathrm{pH}_{\mathrm{i}}$ is not mediated by CFTR in primary cells even though forskolin enhances $\Delta \mathrm{pH}_{\mathrm{i}}$ after IL-4 pretreatment. The results can be readily explained if electrically-coupled $\mathrm{HCO}_{3}{ }^{-}$influx is negligible in primary cells, pendrin mediates most apical anion exchange after IL-4 pretreatment, and forskolin activation of CFTR enhances the anion exchange via pendrin. 
IL-4 alters the expression of many ion transporters and channels (27). To assess the specific contribution of pendrin to $\Delta \mathrm{pH}_{\mathrm{i}}$ we compared IL-4 effects when bronchial cells had been transduced with adenoviruses expressing scrambled or pendrin-specific shRNA. In naïve cells (i.e. that had not been treated with IL-4), intracellular alkalinization was not significant regardless of the adenovirus used; i.e. expressing scrambled $(0.015 \pm 0.018 \mathrm{pH}$ units, $\mathrm{n}=4$; Scr KD, Figure 4A) or pendrin-specific shRNA $(0.047 \pm 0.048 \mathrm{pH}$ units, $\mathrm{n}=4$; PDS KD, Figure 4B). As summarized in Figure 4E, forskolin $(0.024 \pm 0.015$, Scrambled shRNA vs $0.036 \pm 0.007 \mathrm{pH}$ units, Pendrin

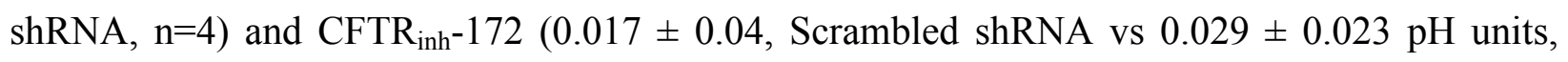
Pendrin shRNA, $\mathrm{n}=4$ ) also had no effect on $\Delta \mathrm{pH}_{\mathrm{i}}$ under these conditions. By contrast, after pretreatment with IL-4 $(10 \mathrm{ng} / \mathrm{ml})$ for 2 days $\Delta \mathrm{pH}_{\mathrm{i}}$ was greatly increased in control cells expressing scrambled shRNA when challenged with apical $\mathrm{Cl}^{-}$-free solution $(0.196 \pm 0.014 \mathrm{pH}$ units, $\mathrm{n}=4$; Figure $4 \mathrm{C}$ ). Importantly, these large $\Delta \mathrm{pH}_{\mathrm{i}}$ responses were reduced $>50 \%$ by adenoviral shRNA targeting pendrin $(0.08 \pm 0.025 \mathrm{pH}$ units, $\mathrm{n}=4$; Figure $4 \mathrm{D})$. Further, $\Delta \mathrm{pH}_{\mathrm{i}}$ was enhanced by $80 \%$ when cells were challenged with apical $\mathrm{Cl}^{-}$-free solution during exposure to forskolin $(0.353 \pm$ $0.025 \mathrm{pH}$ units, $\mathrm{n}=4$ ), pendrin shRNA inhibited this forskolin-dependent stimulation of $\Delta \mathrm{pH}_{\mathrm{i}}$ $(0.201 \pm 0.022 \mathrm{pH}$ units, $\mathrm{n}=4)$, and $\mathrm{CFTR}_{\mathrm{inh}}-172$ inhibited $\Delta \mathrm{pH}_{\mathrm{i}}$ to pre-forskolin levels $(0.115 \pm$ $0.04 \mathrm{pH}$ units, $\mathrm{n}=4)$. These results confirm that IL-4 enhances $\Delta \mathrm{pH}_{\mathrm{i}}$ by increasing pendrinmediated antiport and further suggest that forskolin activation of CFTR enhances anion exchange (Figure 4F).

\section{Pendrin expression increases cAMP-stimulated $\mathrm{HCO}_{3}{ }^{-}$and fluid secretion}

To examine the role of pendrin in forskolin stimulated fluid and $\mathrm{HCO}_{3}^{-}$secretion, primary nasal cells cultured at the air-liquid interface for at least 2 weeks were transduced with scrambled (Scr) 
or pendrin-specific (PDS) shRNA using adenovirus particles and exposed to amiloride and vehicle (0.1\% DMSO) or IL-4 (10 ng/ml) for $48 \mathrm{~h}$ (see MATERIALS AND METHODS). BCECF-dextran was delivered onto the surface by evaporation from perfluorocarbon (FC-72) and confocal imaging was performed 1-2 $\mathrm{h}$ later. Image $\mathrm{z}$-stacks were constructed to determine the ASL height under each condition. Cells were studied under control conditions, after forskolin $(10 \mu \mathrm{M})$ alone, and after treatment with both forskolin and IL-4 (10 ng/ml) using cells from 4 different patients. Images were taken from the same location $\sim 0.88 \mathrm{~mm}$ from the edge of the Transwell. Forskolin increased ASL height in both control (Scr) and pendrin knockdown cells (PDS), and the stimulation by forskolin was larger after treatment with IL-4. The effects of IL-4 and shRNA targeting PDS on ASL height during forskolin stimulation are summarized for $7-9$ monolayers in Fig. 5B. Forskolin stimulation was not affected significantly by shRNA against PDS alone, although compared to Scr, shRNA although there was a trend towards smaller responses. However pretreating cells with both IL-4 and Scr shRNA (Scr KD/IL-4) increased ASL height significantly during forskolin stimulation compared to pretreatment with Scr shRNA alone (Scr KD; $<<0.01, n=7-9$, Fig. 5B). Moreover, this increase was diminished when cells were pretreated with both IL-4 and PDS shRNA (Scr shRNA/IL-4; $<<0.01, \mathrm{n}=9$ ), indicating that the positive effect of IL-4 on forskolinstimulated fluid secretion was pendrin-dependent. The effects of IL-4 and PDS shRNA on ASL height are summarized in Fig. 5B. To measure the volume and $\mathrm{pH}$ of secretions, fluid was collected by aspiration after 2 days and fluid volumes were compared. Changes in ASL volume paralleled those in ASL height, with IL-4 increasing forskolin-stimulated fluid volume 2 -fold $(\mathrm{p}<0.005, \mathrm{n}=8)$ and PDS shRNA blunting the response $(\mathrm{p}<0.05, \mathrm{n}=6)$. Finally, in separate experiments secretions were collected after $48 \mathrm{~h}$ continuous stimulation by $10 \mu \mathrm{M}$ forskolin +200 $\mu \mathrm{M}$ cpt-cAMP and $\mathrm{pH}$ was measured while equilibrated with $5 \% \mathrm{CO}_{2} / 95 \%$ air (5 measurements 
using cells from 3 patients, $\mathrm{n}=3, * \mathrm{p}<0.05, * * \mathrm{p}<0.01$ ). PDS knockdown had little effect on $\mathrm{pH}$ under basal conditions, however pretreatment with IL-4 caused a significant increase in $\mathrm{pH}$ $(p<0.01)$ that was significantly blunted by shRNA targeting pendrin (Figure 5D). These results indicate that pendrin upregulation by IL-4 enhances cAMP-stimulated secretion of both fluid and $\mathrm{HCO}_{3}{ }^{-}$through pendrin-dependent mechanisms.

\section{The IL-4-induced increase in CFTR activity is pendrin-dependent}

If pendrin enhances fluid secretion by increasing cAMP stimulation of CFTR as indicated above, then IL-4 should also increase the short-circuit current $\left(\mathrm{I}_{\mathrm{sc}}\right)$ response to forskolin and the increase should be sensitive to pendrin knockdown. To test those predictions, $\mathrm{I}_{\mathrm{sc}}$ was measured across highly differentiated primary cell cultures after exposure to vehicle (0.1\% DMSO) or IL-4 for 2 days. IL-4 dramatically increased $\mathrm{I}_{\mathrm{sc}}$ stimulation by both forskolin $\left(\Delta \mathrm{I}_{\mathrm{sc}}=4.663 \pm 0.905 \mathrm{vs} 14.06 \pm\right.$ $\left.0.582 \mu \mathrm{A} \mathrm{cm} \mathrm{cm}^{-2}, \mathrm{n}=4, \mathrm{P}<0.0001\right)$ and $\operatorname{ATP}\left(\Delta \mathrm{I}_{\mathrm{sc}}=5.595 \pm 1.071\right.$ vs $14.26 \pm 0.793 \mu \mathrm{A} \mathrm{cm}{ }^{-2}, \mathrm{n}=4$, $\mathrm{P}=0.0003$ ) in nasal cells, indicating that cAMP- and $\mathrm{Ca}^{2+}$-activated anion secretion were both enhanced by IL-4 (Supplementary Figure 3). Larger purinergic responses were expected as they are mediated by TMEM16A, a Ca ${ }^{2+}$-activated $\mathrm{Cl}^{-}$channel that is induced by IL-4 $(20,35)$. Similar results were obtained using well-differentiated bronchial epithelial cells (Supplementary Figure 3C,D). IL-4 induction resulted in 2- to 3-fold larger forskolin responses $\left(\Delta \mathrm{I}_{\mathrm{sc}}=4.7 \pm 0.379 \mathrm{vs} 12.55\right.$ $\left.\pm 1.146 \mu \mathrm{A} \mathrm{cm}{ }^{-2}, \mathrm{n}=4-5, \mathrm{P}=0.0002\right)$ that were sensitive to $\mathrm{CFTR}_{\mathrm{inh}^{-}}-172$, indicating an increase in CFTR activation (Supplementary Figure 3F). CFTR inh $^{-172}$ nearly abolished the forskolin response in both nasal and bronchial cells, indicating that IL-4 enhances CFTR responses to forskolin without increasing CFTR mRNA expression (Figure 2, see also ref (27)). 
IL-4 increases the expression of many genes therefore we examined whether the enhanced forskolin response was due specifically to pendrin. Nasal and bronchial cells that had been pretreated with vehicle or IL-4 for 2 days were transduced with adenoviruses encoding scrambled or pendrin-specific shRNA. Incubating cells with IL-4 increased their responses to forskolin by 2to 3 -fold compared to vehicle (non-CF nasal; $\Delta \mathrm{I}_{\mathrm{sc}}=6.11 \pm 0.624$ vs $13.15 \pm 0.692 \mu \mathrm{A} \mathrm{cm}{ }^{-2}$, nonCF bronchial; $4.24 \pm 0.60$ vs $12.07 \pm 0.778 \mu \mathrm{A} \mathrm{cm} \mathrm{cm}^{-2}, \mathrm{n}=4, \mathrm{P}=0.0002$; Figure 6A,C). This IL-4induced increase was inhibited $>70 \%$ by pendrin shRNA (non-CF nasal $8.348 \pm 1.036 \mu \mathrm{A} \mathrm{cm}{ }^{-2}$, $\mathrm{n}=4, \mathrm{P}=0.008$; non-CF bronchial $7.953 \pm 0.917 \mu \mathrm{A} \mathrm{cm}{ }^{-2}, \mathrm{n}=4, \mathrm{P}=0.014$, Figure $\left.6 \mathrm{~B}, \mathrm{D}\right)$. These results suggest that inducing pendrin expression with IL-4 enhances the activation of CFTR by forskolin. Large ATP-stimulated currents were observed after IL-4 exposure and they were unaffected by pendrin shRNA (non-CF nasal; $\Delta \mathrm{I}_{\mathrm{sc}}=11.6 \pm 0.437$ vs $11.05 \pm 0.668 \mu \mathrm{A} \mathrm{cm}{ }^{-2}, \mathrm{n}=4$, $\mathrm{P}=0.5212$; non-CF bronchial; $13.2 \pm 0.682$ vs $14.35 \pm 0.743 \mu \mathrm{A} \mathrm{cm}{ }^{-2}, \mathrm{n}=4, \mathrm{P}=0.299$ ), consistent with a distinct, pendrin-independent mechanism of action (i.e. increased expression of $\mathrm{Ca}^{2+}$ activated $\mathrm{Cl}^{-}$channels). We conclude from these $\mathrm{I}_{\mathrm{sc}}$ experiments that $\mathrm{IL}-4$ elevates pendrin expression, which in turn enhances the activation of CFTR by cAMP. Such modulation of CFTR would also explain the ability of IL-4 to increase forskolin-stimulated fluid secretion (Figure 5).

\section{Pendrin increases cAMP-stimulated CFTR current in transfected cells}

To study the effect of pendrin on CFTR activity without cytokine induction of other genes we studied whole cell $\mathrm{Cl}^{-}$current in BHK cells stably expressing CFTR. Currents were measured by stepping from a holding potential of $-40 \mathrm{mV}$ to test potentials of -100 to $+100 \mathrm{mV}$ in $20 \mathrm{mV}$ increments under basal conditions and after sequential exposure to forskolin (Fsk, $10 \mu \mathrm{M})$ and CFTR inhibitor $\left(\right.$ CFTR $\left._{\text {Inh }}-172,10 \mu \mathrm{M}\right)$. In cells stably expressing CFTR forskolin activated 80 
$\mathrm{pA} / \mathrm{pF}$ currents that reached a maximum after 6 - 7 minutes. By contrast, forskolin stimulation was faster in cells co-expressing CFTR with EGFP-pendrin and the maximum current was almost doubled (Figure 7A). Current-voltage relations revealed a 5-fold increase in slope conductance in control cells during forskolin stimulation and a 9-fold increase in cells co-expressing pendrin (identified by their green fluorescence; Figure 7B). Forskolin-stimulated current was abolished by CFTRin-172 and was therefore mediated by CFTR (Figure 7A,B). The mean slope conductances measured in the absence and presence of pendrin coexpression are summarized in Figure $7 \mathrm{C}$. These results indicate that pendrin expression enhances forskolin activation of CFTR.

\section{DISCUSSION}

The present studies indicate that pendrin and CFTR are uniformly co-expressed in ciliated cells of the airway surface epithelium in native tissue and have overlapping expression in welldifferentiated primary airway cell cultures. $\mathrm{Most} \mathrm{HCO}_{3}^{-}$secretion across nasal and bronchial epithelial primary cultures pretreated with IL-4 appears mediated by pendrin, which also enhances cAMP activation of CFTR. Pendrin expressed during inflammation would increase luminal $\mathrm{pH}$ through electroneutral, anion exchange-mediated bicarbonate transport while simultaneously increasing the volume of secreted fluid by enhancing cAMP-stimulated, electrogenic chloride flux through CFTR channels.

\section{Pendrin expression and co-localization with CFTR}

Colocalization of CFTR and pendrin at the apical pole of ciliated surface cells is consistent with the previous reports demonstrating CFTR mRNA in bronchial surface epithelium and lamina propria (36), CFTR immunofluorescence in ciliated cells of the airway surface (37), and pendrin 
immunohistochemical staining in mouse airway surface epithelium (23). CFTR and pendrin expression both appeared much lower in submucosal gland serous cells, and neither protein was detected in mucous cells. Low CFTR expression in the glands agrees with some (37) but not all (38) previous studies, and the variable results may simply reflect cellular heterogeneity of CFTR expression in native tissue (39). Impaction of CF submucosal glands in the fetus (40) and extensive studies of secretion by single glands in vitro $(41,42)$ have established beyond doubt that CFTR is functional in glands, although weak immunostaining in glands compared to ciliated surface cells of the bronchus suggests its expression is relatively low.

Pendrin mRNA levels were elevated in primary human bronchial and nasal cell cultures pretreated with the proinflammatory cytokine IL-4, consistent with previous studies $(14,27)$. Under control conditions, pendrin mRNA expression (normalized to GAPDH) appeared 2- to 10-fold lower than CFTR and 10- to 30-fold lower than SLC26A9. Transcripts amplified using different primers cannot be compared quantitatively, nevertheless these large differences confirm that pendrin expression is low under basal conditions and dramatically increases ( $>100$-fold) after IL-4. Upregulation was greater than reported previously ( 30 -fold (27)), perhaps due to differences in cell culture conditions. IL-4 only increased pendrin mRNA expression by $\sim 2.5$-fold in CF bronchial epithelial cells, where pendrin expression was already elevated. High basal pendrin expression implies that CF cells may be in an inflamed state, although that suggestion has been controversial (43) and was not confirmed by measuring inflammatory cytokines and NFKB activity in well differentiated primary bronchial epithelial cells (44). Further studies are needed to understand the mechanism responsible for high basal pendrin expression. Perhaps only some manifestations of inflammation are constitutively increased in CF epithelial cells. 
Unlike tissue sections, CFTR and pendrin expression overlapped only partially in primary cultures; i.e. some ciliated cells expressed both proteins while others expressed only CFTR or pendrin. Further studies are needed to determine if ciliated cells are incompletely differentiated even under ALI conditions. Pendrin was reported exclusively in cells lacking cilia after pretreatment with IL17A (21). We observed apical co-localization of CFTR and pendrin in ciliated cells after IL-4 but cannot exclude the possibility that pendrin is also present in goblet and club cells.

\section{Well-differentiated surface epithelium and Calu-3 cells secrete $\mathrm{HCO}_{3}^{-}$through different mechanisms}

Results obtained with nasal and bronchial primary cells contrast with those from the Calu-3 cell line. Pendrin mRNA levels (after normalization to GAPDH) were much lower (i.e. 20-fold) in Calu-3 under basal conditions and were not increased by IL-4, consistent with our recent findings (7). Stable knockdown of pendrin in Calu-3 cells using lentiviral shRNA reduced pendrin expression measured by qRT- PCR and immunofluorescence staining as expected but did not affect rates of $\mathrm{HCO}_{3}{ }^{-}$or fluid secretion. $\mathrm{HCO}_{3}{ }^{-}$transport under $\mathrm{pH}$-stat conditions and net $\mathrm{HCO}_{3}{ }^{-}$ flux across basolaterally-permeabilized monolayers were also unaffected by pendrin knockdown. In Calu-3 cells, low extracellular $\mathrm{Cl}^{-}$solution produced a large $\Delta \mathrm{pH}_{\mathrm{i}}$ during forskolin activation of CFTR because it is a major determinant of the membrane potential and its activation leads to electrically-coupled $\mathrm{Cl}^{-}$efflux and $\mathrm{HCO}_{3}^{-}$influx (45). This CFTR dependence of $\Delta \mathrm{pH}_{\mathrm{i}}$ in Calu-3 was further suggested by changes in intracellular $\mathrm{pH}$ when apical $\mathrm{Cl}^{-}$and $\mathrm{HCO}_{3}{ }^{-}$concentrations were varied in control and pendrin knockdown cells, but not in CFTR deficient cells (7). Finally, IL-4 had little effect on pendrin expression in Calu-3 and did not alter fluid or $\mathrm{HCO}_{3}^{-}$secretion, 
unlike the primary airway surface cells used in the present study. We conclude that Calu-3 and surface airway epithelial cells are fundamentally different with respect to $\mathrm{HCO}_{3}{ }^{-}$transport and the role of pendrin. Calu-3 is an adenocarcinoma cell line that shares some characteristics with submucosal gland serous cells and is used as a model for them (46-48). The negligible contribution of pendrin to bicarbonate secretion by Calu-3 cells may be appropriate for submucosal gland acinar cells, since we detected little pendrin in glands by immunostaining bronchial sections (Figure 1B).

\section{Pendrin as a potential therapeutic target}

Pendrin modulation of cAMP-stimulated fluid secretion by non-CF cells may contribute to the beneficial effects of beta-agonists used to treat allergic asthma. ASL height was increased on tracheal epithelial cell cultures from pendrin-deficient mice pretreated with IL-13, suggesting that inhibiting pendrin might improve mucus hydration and mucociliary clearance $(24,49)$. Increased ASL height has been observed during exposure to pendrin inhibitors (50) in the absence of cAMP stimulation. Since pendrin promotes cAMP-stimulated fluid secretion it may increase ASL height and mucociliary clearance during cAMP stimulation by endogenous agonists (adenosine, vasoactive intestinal peptide, epinephrine) and by therapeutics used to treat asthma such as betaagonists (51) and phosphodiesterase inhibitors (52). It will be important to exclude adverse effects of pendrin inhibitors on CFTR activation before pursuing them as therapeutics for CF, especially when used in combination with correctors and potentiators that only partially restore CFTR function.

Author disclosures are available with the text of this article at www.atsjournals.org. 


\section{Acknowledgements: The authors thank the Goodman Cancer Research Centre} Histology Facility, McGill University for technical assistance with bronchial tissue histology.

This work was supported by CF Canada, Canadian Institutes of Health Research, and the Canada Foundation for Innovation.

\section{REFERENCES}

1. Frizzell RA, Hanrahan JW. Physiology of chloride and fluid secretion. In: Riordan JR, Boucher RC, Quinton PM, editors. Cystic fibrosis: Molecular basis, physiological changes, and therapeutic strategies. Cold Spring: Cold Spring Harbor Press;2012.

2. Smith JJ, Welsh MJ. Camp stimulates bicarbonate secretion across normal, but not cystic fibrosis airway epithelia. JClinInvest 1992;89:1148-1153.

3. Gray MA, Pollard CE, Harris A, Coleman L, Greenwell JR, Argent BE. Anion selectivity and block of the small conductance chloride channel on pancreatic duct cells. AmJPhysiolCell Physiol 1990;259:C752-C761.

4. Poulsen JH, Fischer H, Illek B, Machen TE. Bicarbonate conductance and ph regulatory capability of cystic fibrosis transmembrane conductance regulator. ProcNatlAcadSciUSA 1994;91:5340-5344.

5. Linsdell P, Tabcharani JA, Rommens JM, Hou Y-X, Chang X-B, Tsui L-C, Riordan JR, Hanrahan JW. Permeability of wild-type and mutant cystic fibrosis transmembrane conductance regulator chloride channels to polyatomic anions. JGenPhysiol 1997;110:355-364.

6. Hanrahan JW, Tabcharani JA, Chang X-B, Riordan JR. A secretory cl channel from epithelial cells studied in heterologous expression systems. In: Gerenscer G, editor. Electrogenic cl- transporters in biological membranes: Springer Verlag;1994. p. 193-220.

7. Huang J, Kim D, Shan J, Abu-Arish A, Luo Y, Hanrahan JW. Most bicarbonate secretion by calu-3 cells is mediated by cftr and independent of pendrin. Physiol Rep 2018;6(5):e13641.

8. Devor DC, Singh AK, Lambert LC, DeLuca A, Frizzell RA, Bridges RJ. Bicarbonate and chloride secretion in calu-3 human airway epithelial cells. JGenPhysiol 1999;113:743-760.

9. Shan J, Huang J, Liao J, Robert R, Hanrahan JW. Anion secretion by a model epithelium: More lessons from calu-3. Acta Physiol 2011;202:523-531.

10. Shan J, Liao J, Huang J, Robert R, Palmer ML, Fahrendrug SC, O'Grady SM, Hanrahan JW. Bicarbonatedependent chloride transport drives fluid secretion by the human airway epithelial cell line calu-3. JPhysiol 2012;590:5273-5297.

11. Al-Bazzaz FJ. Role of cyclic amp in regulation of chloride secretion by canine tracheal mucosa. AmRevRespirDis 1981;123:295-298.

12. Welsh MJ. Inhibition of chloride secretion by furosemide in canine tracheal epithelium. JMembrBiol 1983;71:219-226.

13. Nofziger C, Dossena S, Suzuki S, Izuhara K, Paulmichl M. Pendrin function in airway epithelia. Cellular physiology and biochemistry : international journal of experimental cellular physiology, biochemistry, and pharmacology 2011;28(3):571-578.

14. Pedemonte N, Caci E, Sondo E, Caputo A, Rhoden K, Pfeffer U, Di Candia M, Bandettini R, Ravazzolo R, Zegarra-Moran 0, et al. Thiocyanate transport in resting and il-4-stimulated human bronchial epithelial cells: Role of pendrin and anion channels. JImmunol 2007;178:5144-5153.

15. Soleimani M, Greeley T, Petrovic S, Wang ZH, Amlal H, Kopp P, Burnham CE. Pendrin: An apical cl(-)/oh(-)/hco(3)(-) exchanger in the kidney cortex. Am J Physiol-Renal 2001;280(2):F356-F364. 
16. Royaux IE, Wall SM, Karniski LP, Everett LA, Suzuki K, Knepper MA, Green ED. Pendrin, encoded by the pendred syndrome gene, resides in the apical region of renal intercalated cells and mediates bicarbonate secretion. Proceedings of the National Academy of Sciences of the United States of America 2001;98(7):42214226.

17. Scott DA, Karniski LP. Human pendrin expressed in xenopus laevis oocytes mediates chloride/formate exchange. Am J Physiol-Cell Ph 2000;278(1):C207-C211.

18. Scott DA, Wang R, Kreman TM, Sheffield VC, Karniski LP. The pendred syndrome gene encodes a chloride-iodide transport protein. Nat Genet 1999;21(4):440-443.

19. Danahay H, Atherton H, Jones G, Bridges RJ, Poll CT. Interleukin-13 induces a hypersecretory ion transport phenotype in human bronchial epithelial cells. AmJPhysiolLung CellMolPhysiol 2002;282:L226-L236. 20. Galietta LJ, Pagesy P, Folli C, Caci E, Romio L, Costes B, Nicolis E, Cabrini G, Goossens M, Ravazzolo R, et al. Il-4 is a potent modulator of ion transport in the human bronchial epithelium in vitro. JImmunol 2002;168:839-845.

21. Adams KM, Abraham V, Spielman D, Kolls JK, Rubenstein RC, Conner GE, Cohen NA, Kreindler JL. Il-17a induces pendrin expression and chloride-bicarbonate exchange in human bronchial epithelial cells. PLoS One 2014;9(8):e103263.

22. Scanlon KM, Gau Y, Zhu J, Skerry C, Wall SM, Soleimani M, Carbonetti NH. Epithelial anion transporter pendrin contributes to inflammatory lung pathology in mouse models of bordetella pertussis infection. Infection and immunity 2014;82(10):4212-4221.

23. Nakao I, Kanaji S, Ohta S, Matsushita H, Arima K, Yuyama N, Yamaya M, Nakayama K, Kubo H, Watanabe $\mathrm{M}$, et al. Identification of pendrin as a common mediator for mucus production in bronchial asthma and chronic obstructive pulmonary disease. JImmunol 2008;180:6262-6269.

24. Nakagami Y, Favoreto S, Jr., Zhen G, Park SW, Nguyenvu LT, Kuperman DA, Dolganov GM, Huang X, Boushey HA, Avila PC, et al. The epithelial anion transporter pendrin is induced by allergy and rhinovirus infection, regulates airway surface liquid, and increases airway reactivity and inflammation in an asthma model. Journal of immunology 2008;181(3):2203-2210.

25. Wills-Karp M, Luyimbazi J, Xu X, Schofield B, Neben TY, Karp CL, Donaldson DD. Interleukin-13: Central mediator of allergic asthma. Science 1998;282(5397):2258-2261.

26. Kuperman DA, Lewis CC, Woodruff PG, Rodriguez MW, Yang YH, Dolganov GM, Fahy JV, Erle DJ. Dissecting asthma using focused transgenic modeling and functional genomics. The Journal of allergy and clinical immunology 2005;116(2):305-311.

27. Gorrieri G, Scudieri P, Caci E, Schiavon M, Tomati V, Sirci F, Napolitano F, Carrella D, Gianotti A, Musante I, et al. Goblet cell hyperplasia requires high bicarbonate transport to support mucin release. Scientific reports 2016;6:36016.

28. Ko SBH, Shcheynikov N, Choi JY, Luo X, Ishibashi K, Thomas PJ, Kim JY, Kim KH, Lee MG, Naruse S, et al. A molecular mechanism for aberrant cftr-dependent $\mathrm{hco}_{3}{ }^{-}$transport in cystic fibrosis. EMBO J 2002;21:56625672.

29. Ko SBH, Zeng W, Dorward MR, Luo X, Kim KH, Millen L, Goto H, Naruse S, Soyombo A, Thomas PJ, et al. Gating of cftr by the stas domain of slc26 transporters. Nature Cell Biol 2004;6:343-350.

30. Avella M, Loriol C, Boulukos K, Borgese F, Ehrenfeld J. Slc26a9 stimulates cftr expression and function in human bronchial cell lines. J Cell Physiol 2011;226(1):212-223.

31. Kim D, Kim J, Burghardt B, Best L, Steward MC. Role of anion exchangers in cl- and hco3- secretion by the human airway epithelial cell line calu-3. American journal of physiology Cell physiology 2014;307(2):C208219.

32. Huang J, Shan J, Kim D, Liao J, Evagelidis A, Alper SL, Hanrahan JW. Basolateral chloride loading by ae2: Role in fluid secretion by the human airway epithelial cell line calu-3. JPhysiol 2012;590:5273-5316.

33. Bertrand CA, Zhang R, Pilewski JM, Frizzell RA. Slc26a9 is a constitutively active, cftr-regulated anion conductance in human bronchial epithelia. JGenPhysiol 2009;133:421-438.

34. Garnett JP, Hickman E, Burrows R, Hegyi P, Tiszlavicz L, Cuthbert AW, Fong P, Gray MA. Novel role for pendrin in orchestrating bicarbonate secretion in cystic fibrosis transmembrane conductance regulator (cftr)expressing airway serous cells. JBiolChem 2011;286:41069-41082.

35. Caputo A, Caci E, Ferrera L, Pedemonte N, Barsanti C, Sondo E, Pfeffer U, Ravazzolo R, Zegarra-Moran 0 , Galietta LJ. Tmem16a, a membrane protein associated with calcium-dependent chloride channel activity. Science 2008;322:590-594.

36. Trezise AEO, Buchwald M. In vivo cell-specific expression of the cystic fibrosis transmembrane 
conductance regulator. Nature 1991;353:434-437.

37. Kreda SM, Mall M, Mengos A, Rochelle L, Yankaskas J, Riordan JR, Boucher RC. Characterization of wildtype and f508 cystic fibrosis transmembrane regulator in human respiratory epithelia. MolBiolCell 2005;16:2154-2167.

38. Engelhardt JF, Zepeda M, Cohn JA, Yankaskas JR, Wilson JM. Expression of the cystic fibrosis gene in adult human lung. JClinInvest 1994;93:737-749.

39. Jiang Q Engelhardt JF. Cellular heterogeneity of cftr expression and function in the lung: Implications for gene therapy of cystic fibrosis. EurJHumGenet 1998;6:12-31.

40. Ornoy A, Arnon J, Katznelson D, Granat M, Caspi B, Chemke J. Pathological confirmation of cystic fibrosis in the fetus following prenatal diagnosis. AmJMedGenet 1987;28:935-947.

41. Widdicombe JH, Wine JJ. Airway gland structure and function. Physiol Rev 2015;95(4):1241-1319.

42. Ballard ST, Inglis SK. Liquid secretion properties of airway submucosal glands. JPhysiol 2004;556:1-

10.

43. Machen TE. Innate immune response in cf airway epithelia: Hyperinflammatory? AmJPhysiolCell Physiol 2006;291:C218-C230.

44. Becker MN, Sauer MS, Muhlebach MS, Hirsch AJ, Wu Q, Verghese MW, Randell SH. Cytokine secretion by cystic fibrosis airway epithelial cells. AmJRespirCritCare Med 2004;169:645-653.

45. Tamada T, Hug MJ, Frizzell RA, Bridges RJ. Microelectrode and impedance analysis of anion secretion in calu-3 cells. JOP 2001;2:219-228.

46. Haws CM, Finkbeiner WE, Widdicombe JH, Wine JJ. Calu-3, a model cftr expressing cell line: Novel features of cftr channel regulation. PedPulmonol 1993;suppl.9:215-216.

47. Shen B-Q, Finkbeiner WE, Wine JJ, Mrsny RJ, Widdicombe JH. Calu-3: A human airway epithelial cell line that shows camp-dependent cl- secretion. AmJPhysiolLung CellMolPhysiol 1994;266:L493-L501.

48. Haws C, Finkbeiner WE, Widdicombe JH, Wine JJ. Cftr in calu-3 human airway cells: Channel properties and role in camp-activated cl- conductance. AmJPhysiolLung CellMolPhysiol 1994;266:L502-L512.

49. Lee HJ, Yoo JE, Namkung W, Cho HJ, Kim K, Kang JW, Yoon JH, Choi JY. Thick airway surface liquid volume and weak mucin expression in pendrin-deficient human airway epithelia. Physiol Rep 2015;3(8).

50. Haggie PM, Phuan PW, Tan JA, Zlock L, Finkbeiner WE, Verkman AS. Inhibitors of pendrin anion exchange identified in a small molecule screen increase airway surface liquid volume in cystic fibrosis. FASEB journal : official publication of the Federation of American Societies for Experimental Biology 2016.

51. Billington CK, Penn RB, Hall IP. Beta2 agonists. Handbook of experimental pharmacology 2017;237:23-

40.

52. Franciosi LG, Diamant Z, Banner KH, Zuiker R, Morelli N, Kamerling IM, de Kam ML, Burggraaf J, Cohen AF, Cazzola M, et al. Efficacy and safety of rpl554, a dual pde3 and pde4 inhibitor, in healthy volunteers and in patients with asthma or chronic obstructive pulmonary disease: Findings from four clinical trials. The lancet Respiratory medicine 2013;1(9):714-727. 


\section{FIGURES}

Figure 1. Pendrin expression in bronchial tissue and primary airway epithelial cells. $(A)$ Surface epithelium in normal bronchial tissue sections (EP: epithelium) showing apical CFTR and pendrin (PDS) expression (scale bar $50 \mu \mathrm{m}$ ). An example of immunostaining without primary antibody $\left(\mathrm{WO}^{\circ}\right)$ and the corresponding bright field image are shown in lower images (representative of $n=4$ samples from one CF patient and $n=4$ samples from one non-CF donor). (B) Immunostaining for CFTR and pendrin in bronchial submucosa. No CFTR or pendrin was detected in submucosal gland mucous cells (MC). Weak CFTR and pendrin signals were observed in serous cells of the submucosal glands (SC), however they were not localized at the apical membrane (scale bar $50 \mu \mathrm{m}$ ). Background staining without primary antibody (WO $1^{\circ}$ ) and brightfield image with DAPI stained nuclei are shown in lower images (representative of $n=4$ samples from one nonCF donor). (C) Detection of pendrin in non-CF nasal, non-CF bronchial, and CF bronchial cells after treatment with either vehicle $(0.1 \%$ DMSO, left images) or with IL-4 $(10 \mathrm{ng} / \mathrm{ml}$, right images) for 2 days. Note that IL-4 increased pendrin immunostaining in all three surface epithelial cell types ( $x y$ view; scale bar $20 \mu \mathrm{m}$ ). Pendrin immunostaining was already elevated in CF bronchial epithelial cells under basal conditions and was further increased by IL-4 (representative of $n=16$ samples from 4 different non-CF donors, and $\mathrm{n}=12$ samples from 3 different CF patients). (D) $x-z$ view showing pendrin immunostaining localized at the apical pole of normal and CF bronchial cells following treatment with IL-4 for 2 days (scale bar $10 \mu \mathrm{m}, \mathrm{AP}$ :apical, BL:basolateral). (E) Top view shows partial co-localization of CFTR and pendrin (indicated by yellow) in a subset of bronchial epithelial cells cultured at the air-liquid interface (white arrowheads, 
representative of $\mathrm{n}=8$ samples from 4 different non-CF donors). $(F)$ Co-localization of CFTR (green band) and pendrin (PDS, red band indicated by white arrowheads) at the apical membrane of individual ciliated cells that had been isolated from air-liquid interface cultures after $48 \mathrm{~h}$ exposure to IL-4 (representative of $\mathrm{n}=12$ samples from 4 different non-CF donors).

Figure 2. CFTR, pendrin and SLC26A9 mRNA expression in surface airway epithelia and the effect of IL-4 on pendrin in each cell type. (A-D) CFTR, SLC26A4 (A4) and SLC26A9 (A9) mRNA levels in well-differentiated primary cultures measured using qRT-PCR. $(A)$ non-CF nasal epithelial cells, $(B)$ non-CF bronchial epithelial cells, $(C)$ CF bronchial epithelial cells containing F508del/F508del CF, (D) Calu-3 cell line (submucosal gland serous cell). mRNA levels were normalized to GAPDH. (E-H) Effect of IL-4 (10 ng/ml, 2 days) on pendrin expression in $(E)$ nasal, $(F)$ non-CF bronchial, $(G)$ CF bronchial epithelial cells and $(H)$ Calu-3. $(I)$ CFTR and pendrin mRNA levels in untreated vs IL-4-treated nonCF and CF bronchial epithelial cells. Expression is shown relative to control, DMSO treated non-CF cells (Mean \pm s.e., $n=4-7 ;{ }^{*} p<0.05,{ }^{* * *} p<0.001$, Student's $t$-test).

Figure 3. Effect of IL4 on the intracellular $\mathrm{pH}$ response $\left(\Delta \mathrm{pH}_{\mathrm{i}}\right)$ to apical $\mathrm{Cl}^{-}$removal in nasal and bronchial epithelial cells. Intracellular pHi was measured while $\mathrm{Cl}^{-}$in $\mathrm{HCO}_{3}{ }^{-}$ buffered apical solution was replaced with gluconate. Well-differentiated non-CF nasal $(A-C)$ and bronchial $(D-E)$ epithelial cells. $(A) \mathrm{pH}_{\mathrm{i}}$ in cells pretreated with vehicle $(0.1 \%$ DMSO). (B) $\mathrm{pH}_{\mathrm{i}}$ after pretreatment with $10 \mathrm{ng} / \mathrm{ml} \mathrm{IL-4}$ for 2 days. The dashed line indicates the rate of re-acidification $\mathrm{dpHi} / \mathrm{dt}$ that results from $\mathrm{HCO}_{3}{ }^{-}$efflux when extracellular $\mathrm{Cl}^{-}$is 
restored on the apical side. $(C) \mathrm{pH}_{\mathrm{i}}$ when apical $\mathrm{Cl}^{-}$was substituted with gluconate followed by iodide. Note the re-acidification rate with extracellular $\mathrm{I}$ - is similar to that with $\mathrm{Cl}^{-}$in panel $\mathrm{B}$. (D) Effect of apical $\mathrm{Cl}^{-}$replacement on $\mathrm{pH}_{\mathrm{i}}$ in well differentiated primary bronchial epithelial cells under control conditions and during forskolin stimulation. Cells were pretreated with vehicle $\left(0.1 \%\right.$ DMSO) for 2 days then perfused with $\mathrm{HCO}_{3}^{-}$-buffered solution with or without forskolin. (E) Same conditions as in $(D)$ except cells were pretreated for 2 days with $10 \mathrm{ng} / \mathrm{ml}$. Note much larger responses to apical $\mathrm{Cl}^{-}$and enhanced response during forskolin stimulation. $(F)$ Effect of IL-4 pretreatment on the initial rate of re-acidification after restoring extracellular $\mathrm{Cl}^{-}$, and when $\mathrm{I}^{-}$is restored to assess selectivity (mean \pm s.e.m. $n \geq 4$ experiments, ${ }^{*} p<0.05$, one-way ANOVA). (G) Summary of $\Delta \mathrm{pH}_{\mathrm{i}}$ induced by substituting apical $\mathrm{Cl}^{-}$with gluconate without vs with IL-4 pretreatment to upregulate pendrin, and in the absence or presence of forskolin to activate CFTR. Note the larger response after IL-4, and increased response to forskolin after IL-4 pretreatment (Mean \pm s.e., $\mathrm{n}=8,{ }^{* * *} \mathrm{p}<0.001$ ).

Figure 4. Effect of pendrin knockdown on $\Delta \mathrm{pHi}$ responses to apical $\mathrm{Cl}^{-}$removal in control and IL-4 pretreated cells. Well differentiated primary human bronchial epithelial (pHBE) cells were transduced with adenovirus particles expressing scrambled or pendrin-specific shRNA under control conditions (naive) or in combination with $10 \mathrm{ng} / \mathrm{ml} \mathrm{IL-4}$ for 2 days. After loading with the $\mathrm{pH}$ indicator BCECF-AM cells were exposed to $\mathrm{Cl}^{-}$-free apical solution sequentially under control conditions, in the presence of forskolin (FSK), and in the presence of FSK + CFTR inh -172. $(A)$ naive pHBE cells transduced with scrambled shRNA. (B) effect of pendrin knock down in naive pHBE cells, $(C) \Delta \mathrm{pH}_{\mathrm{i}}$ after IL-4 induction 
of pHBE cells transduced with scrambled shRNA, $(D) \Delta \mathrm{pH}_{\mathrm{i}}$ after IL-4 induction of pHBE cells transduced with pendrin shRNA, $(E)$ summary of $\Delta \mathrm{pH}_{\mathrm{i}}$ in naive cells transduced with scrambled and pendrin shRNA adenoviruses (mean \pm s.e. $\mathrm{n}=3$ ), $(F)$ summary of $\Delta \mathrm{pH}_{\mathrm{i}}$ in IL-4 treated cells transduced with scrambled or pendrin shRNA adenoviruses (mean \pm s.e. $\mathrm{n}=4,{ }^{*} \mathrm{p}<0.05$, student's $t$-test).

Figure 5. Role of pendrin in IL-4-induced, forskolin-stimulated secretion by nasal epithelial cells. Non-CF nasal inferior turbinate cells were cultured for at least 2 weeks at the air-liquid interface, then transduced with adenovirus particles directing expression of scrambled (Scr) or pendrin (PDS) shRNA. $(A)$ Non-CF nasal inferior turbinate cells were exposed to amiloride $(10 \mu \mathrm{M})$ to inhibit fluid absorption for $48 \mathrm{~h}$ along with either vehicle (0.1\% DMSO, top row), $10 \mu \mathrm{M}$ forskolin (second row), or both forskolin + IL-4 (10 $\mathrm{ng} \mathrm{ml}^{-}$ ${ }^{1}$, third row). Note that pendrin shRNA reduced ASL height during forskolin stimulation. Image stacks are representative of $n=8$ cultures from 4 different patients. (B) Summary of ASL heights measured during forskolin stimulation (mean \pm s.e., $n=7-9$, ${ }^{* *} p<0.01$, student's t-test). (C) Total forskolin-stimulated fluid volume on Scr and PDS cells when pretreated with vehicle $(0.1 \% \mathrm{DMSO})$ or IL-4 $\left(10 \mathrm{ng} \mathrm{ml}^{-1}\right)$ in the presence of amiloride (10 $\mu \mathrm{M})$. Accumulated fluid was collected by aspiration after $48 \mathrm{~h}$ stimulation (mean \pm s.e.m., $\left.\mathrm{n}=7-9,{ }^{*} \mathrm{p}<0.05,{ }^{* * *} \mathrm{p}<0.001\right)$. Note that the IL-4-dependent fluid secretion during forskolin stimulation was significantly reduced in PDS cells. $(D) \mathrm{pH}$ of apical secretions by cells from 3 donors after $48 \mathrm{~h}$ stimulation with $10 \mu \mathrm{M}$ forskolin $+200 \mu \mathrm{M}$ cpt-cAMP $(5$ cultures total, $\mathrm{n}=3$ donors, $\left.{ }^{*} \mathrm{p}<0.05,{ }^{* *} \mathrm{p}<0.01\right)$. IL-4 increased both the volume and $\mathrm{pH}$ of fluid secreted during cAMP stimulation, and both these effects of IL-4 were inhibited 
by shRNA targeting pendrin.

Figure 6. Effect of pendrin knockdown on IL-4 and forskolin-stimulated anion secretion by surface epithelial cells. The effect of pendrin knockdown (PDS KD) using shRNA adenovirus when surface airway epithelial cells were pretreated with vehicle $(0.1 \%$ DMSO) or IL-4 (10 ng/ml) for 2 days. (A) Recordings of $\mathrm{I}_{\mathrm{sc}}$ across naïve (i.e. no exposure to IL-4), IL-4 pretreated, and IL-4 + pendrin shRNA-pretreated nasal epithelial cells sequentially exposed to forskolin (Fsk), CFTR inh -172 and ATP. (B) Summary of nasal cell responses to forskolin (Fsk) or ATP in naïve, IL-4 pretreated (10 ng/ml, 2 days) and IL-4+pendrin shRNA cells. shPDS reduced the forskolin stimulated $I_{\mathrm{sc}}$ but not the ATP-stimulated $\mathrm{I}_{\mathrm{sc}}$ after induction by IL-4. (C) Bronchial cell responses under same conditions as in $(A)$. $(D)$ Summary of mean $\mathrm{I}_{\mathrm{sc}}$ response to forskolin and ATP in bronchial epithelial cells under same conditions as in $(B)$. Note that in both cell types, pendrin knockdown attenuates forskolin-stimulated currents but not ATP-stimulated currents. Mean \pm s.e., $n=12,{ }^{* *} p<$ 0.01 , NS not significant.

Figure 7. Effect of co-expressing pendrin on CFTR current in BHK cells. EGFP-pendrin was transiently transfected into BHK cells that stably express wild-type CFTR and whole cell $\mathrm{Cl}^{-}$currents were measured during sequential exposure to control solution, forskolin $(10 \mu \mathrm{M})$ and the CFTR inhibitor $\left(\right.$ CFTR $\left._{\operatorname{Inh}}-172,10 \mu \mathrm{M}\right) .(A)$ Time-course of whole-cell anion current activation by forskolin and inhibition by CFTR $_{\text {inh }}-172$ with and without pendrin co-expression. (B) Currents elicited by stepping from $-40 \mathrm{mV}$ holding potential to test potentials ranging from -100 to $+100 \mathrm{mV}$ in $20 \mathrm{mV}$ increments, normalized to 
membrane area (cell capacitance). Purple and orange lines show forskolin-stimulated current without and with pendrin co-expression, respectively. Blue and red lines show basal currents and stimulated currents after inhibition with $\mathrm{CFTR}_{\mathrm{inh}}-172$. Means \pm s.e., $n$ $=7-8$ cells. $(C)$ Histogram comparing mean whole-cell conductance without (purple) or with (orange) pendrin co-expression. Conductance was determined by linear fit of the entire cell I/V relationship (mean \pm s.d., $n=7-8,{ }^{* * *} p<0.001$ Student's t-test). 

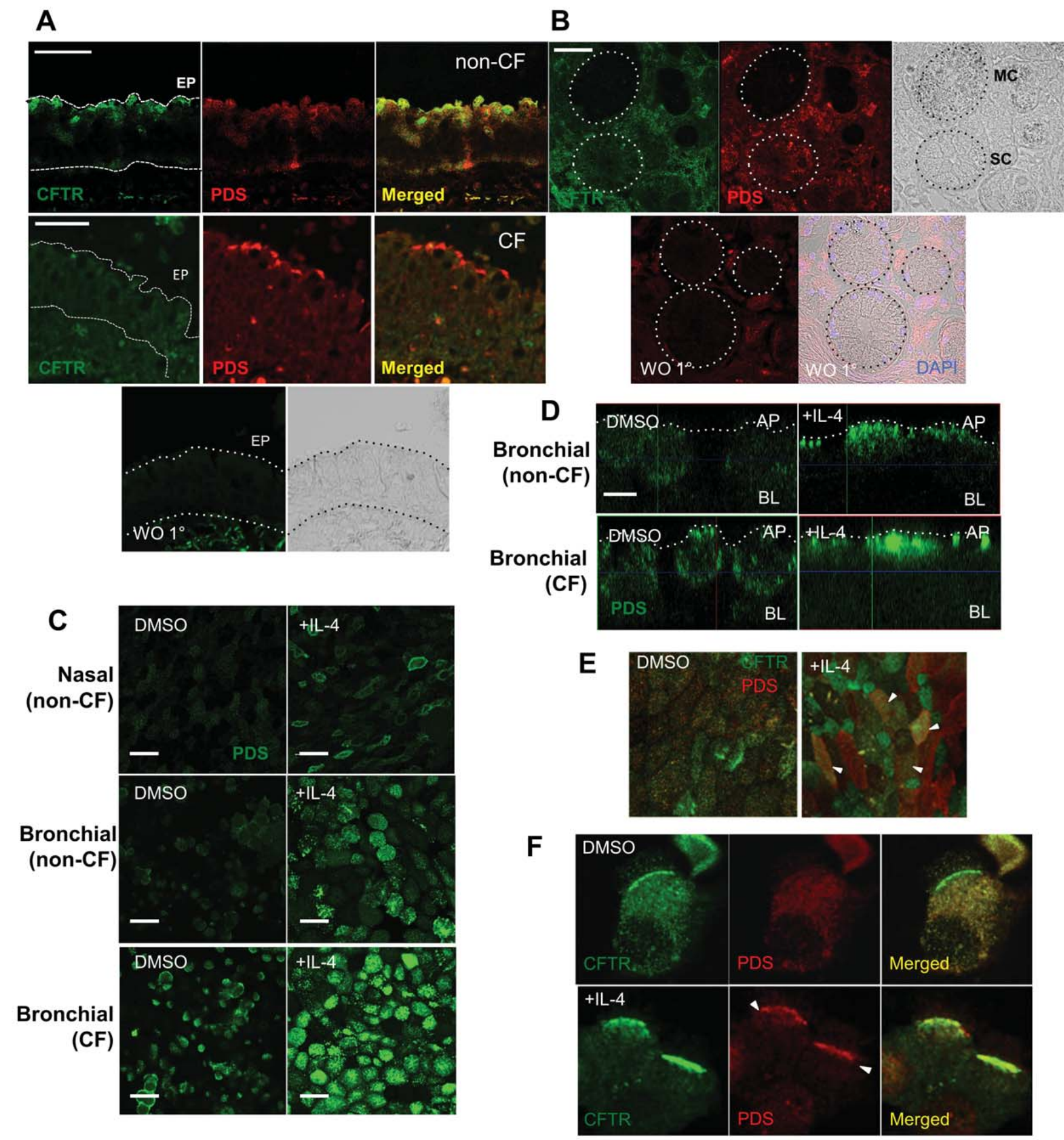

\section{Figure 1}

Figure 1. Pendrin expression in bronchial tissue and primary airway epithelial cells. 

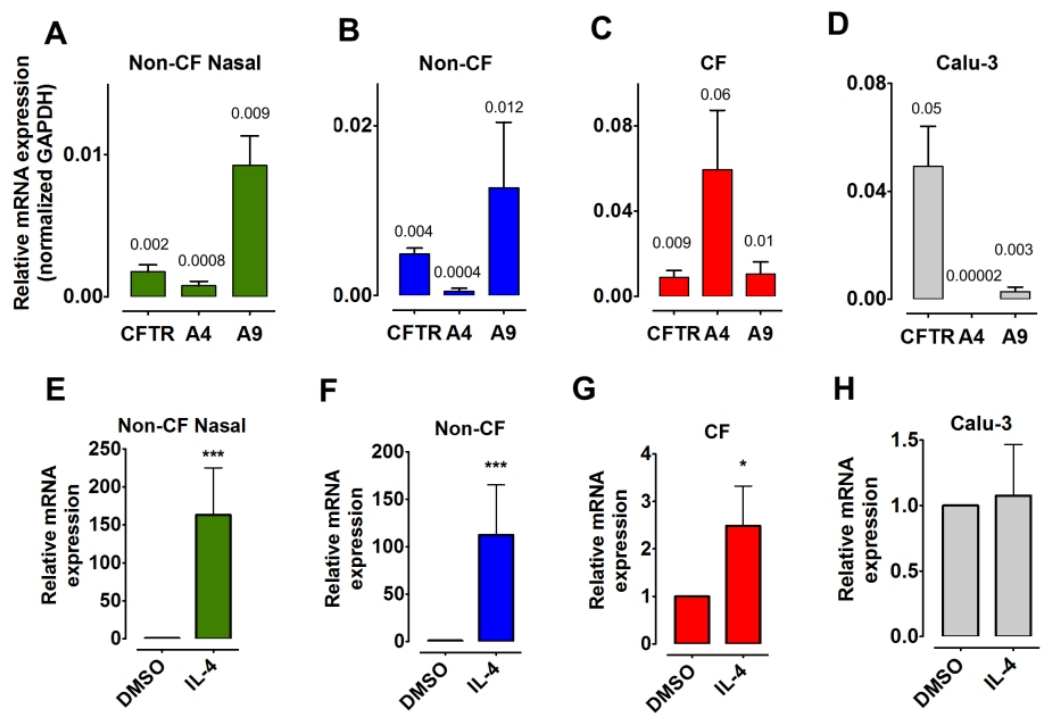

\section{$\mathbf{F}$}

G
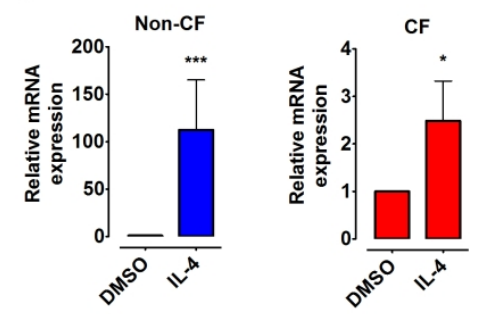

H
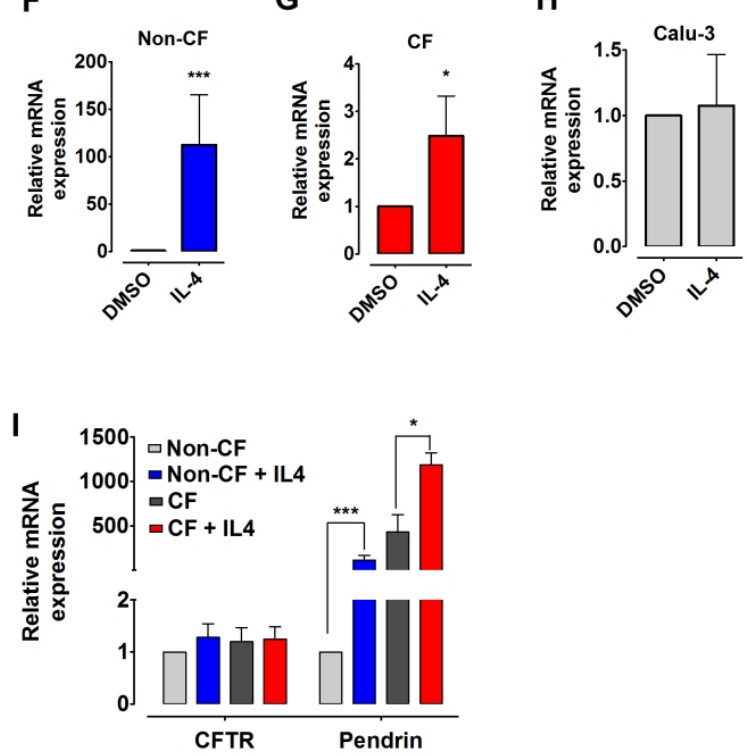

Figure 2

Figure 2. CFTR, pendrin and SLC26A9 mRNA expression in surface airway epithelia and the effect of IL-4 on pendrin in each cell type.

$215 \times 276 \mathrm{~mm}(300 \times 300 \mathrm{DPI})$ 


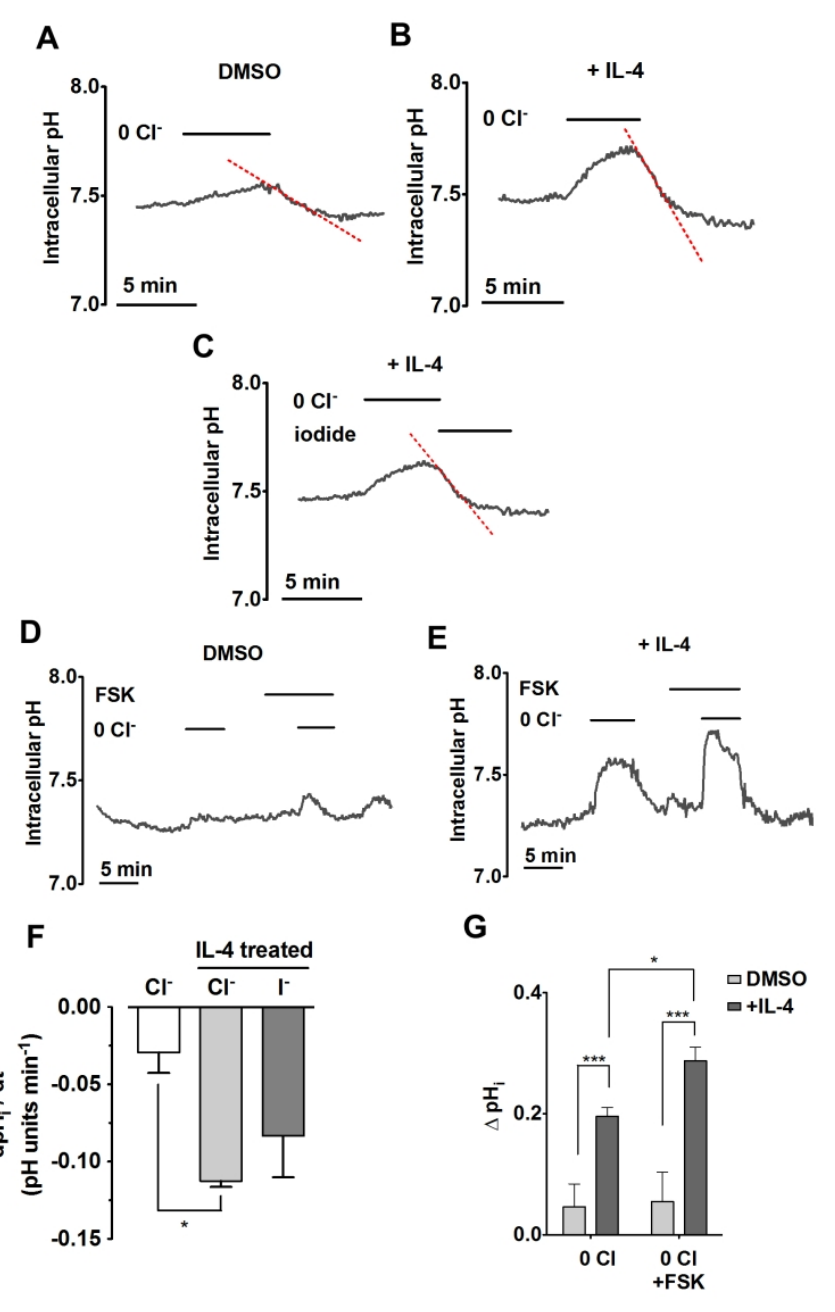

Figure 3

Figure 3. Effect of IL4 on the intracellular $\mathrm{pH}$ response $(\Delta \mathrm{pHi})$ to apical $\mathrm{Cl}$ - removal in nasal and bronchial epithelial cells.

$215 \times 276 \mathrm{~mm}(300 \times 300 \mathrm{DPI})$ 


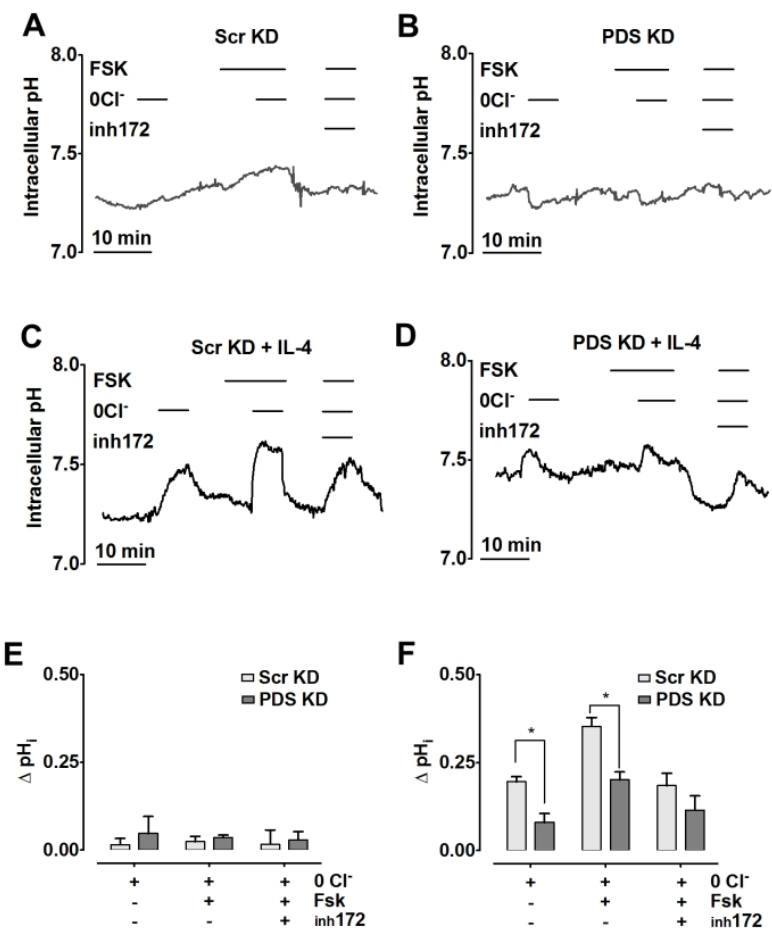

Figure 4

Figure 4. Effect of pendrin knockdown on $\Delta \mathrm{pHi}$ responses to apical $\mathrm{Cl}$ - removal in control and IL-4 pretreated cells.

$215 \times 276 \mathrm{~mm}(300 \times 300 \mathrm{DPI})$ 

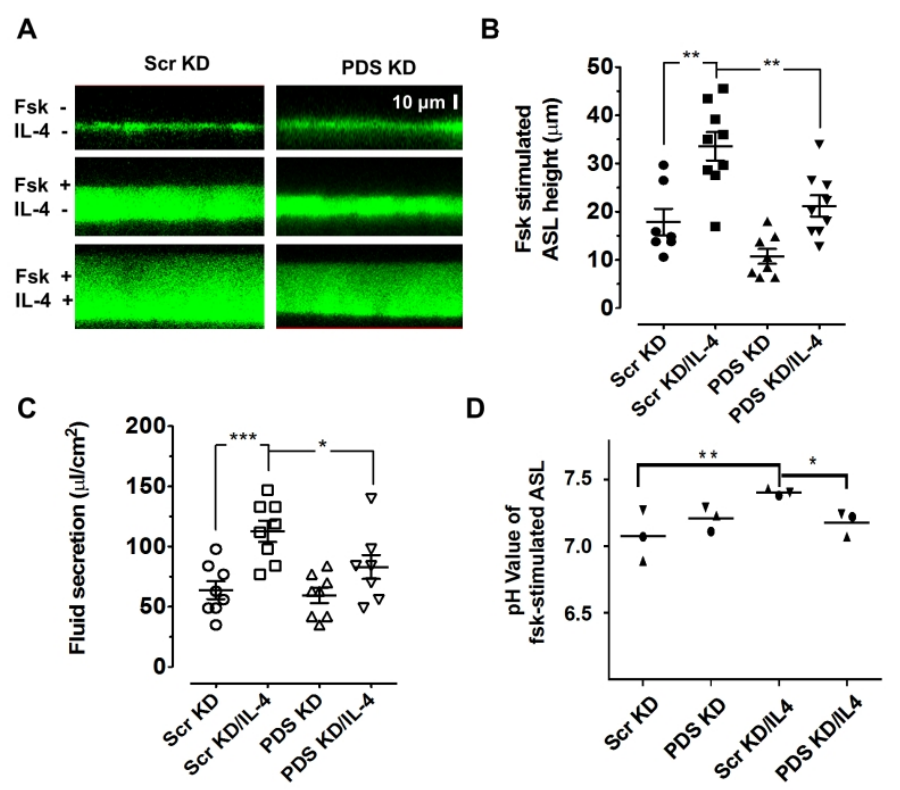

Figure 5

Figure 5. Role of pendrin in IL-4-induced, forskolin-stimulated secretion by nasal epithelial cells. $215 \times 276 \mathrm{~mm}(300 \times 300 \mathrm{DPI})$ 
A

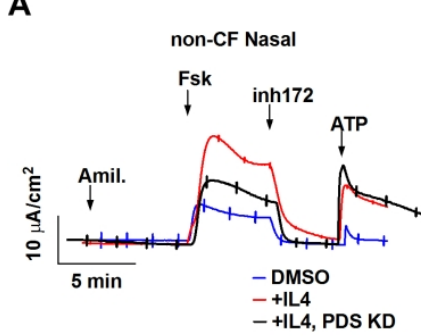

C

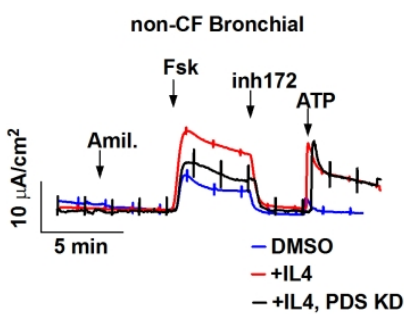

B

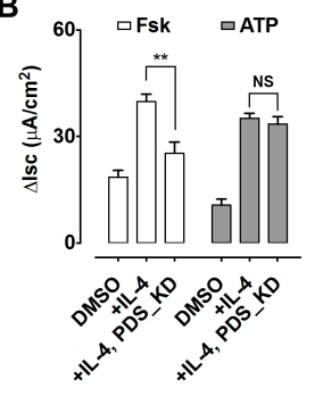

D

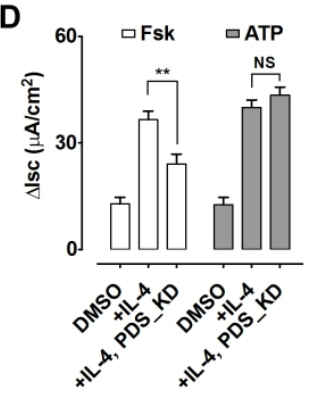

Figure 6

Figure 6. Effect of pendrin knockdown on IL-4 and forskolin-stimulated anion secretion by surface epithelial cells.

$215 \times 276 \mathrm{~mm}(300 \times 300 \mathrm{DPI})$ 
A

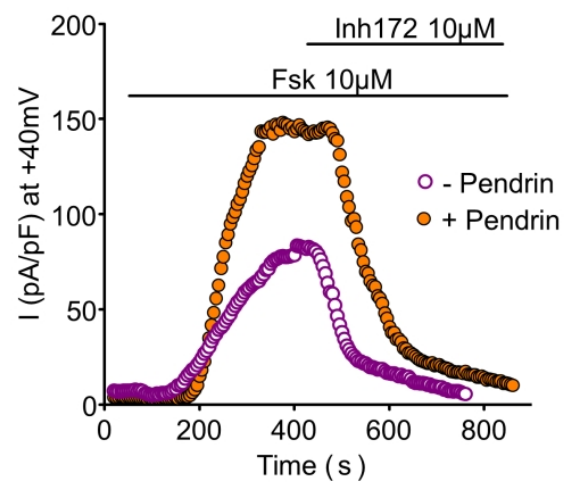

B

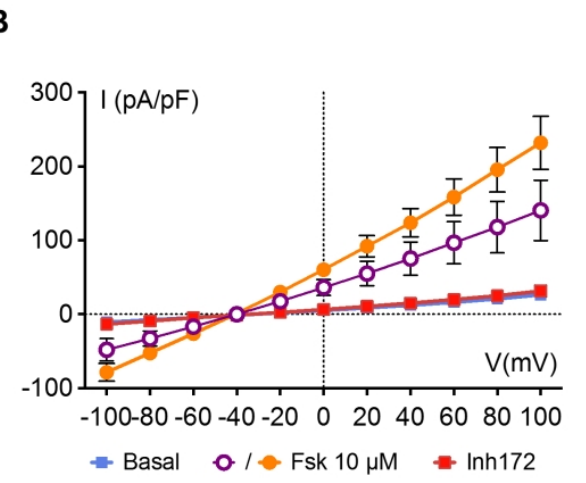

C

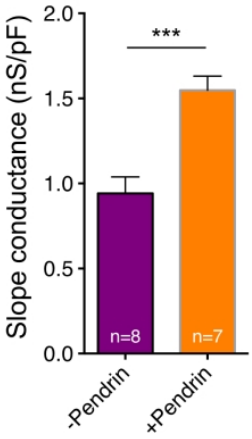

Figure 7

Figure 7. Effect of co-expressing pendrin on CFTR current in BHK cells. $215 \times 276 \mathrm{~mm}(300 \times 300 \mathrm{DPI})$ 


\section{SUPPLEMENTAL INFORMATION}

MATERIALS AND METHODS (SUPPLEMENTARY)

Human airway tissue and cells

Lung samples from $5 \mathrm{CF}$ patients $(\mathrm{F} 508 \mathrm{del} / \mathrm{F} 508 \mathrm{del})$ undergoing lung transplantation were obtained from the Institut de recherches cliniques de Montréal (IRCM) and Centre hospitalier de l'Université de Montréal (CHUM). Non-CF lungs from 7 donors were provided National Development and Research Institutes, Inc. (NDRI, New York, NY) and the International Institute for the Advancement of Medicine (IIAM, Edison NJ). Nasal tissue from 11 patients undergoing surgery for obstruction was collected at St. Mary Hospital, Jewish General Hospital, Royal Victoria Hospital and LaSalle Hospitals in Montréal. Samples were obtained with informed consent following protocols approved by the Institutional Review Boards of the IRCM and McGill University (\#A08-M70-14B). Cells were isolated by the Primary Airway Cell Biobank at the McGill Cystic Fibrosis Translational Research center (CFTRc) and maintained in differentiation medium (Opti-MEM; Life Technologies Inc., Burlington ON) with supplements at the air-liquid interface (ALI) for 28 - 30 days as described (53).

\section{Histology}

For histological studies, primary cell cultures were, then washed with PBS, fixed in 10\% neutral buffered formalin (pH 6.8 - 7.2, EMD Chemicals Inc.) overnight at $4^{\circ} \mathrm{C}$, embedded in paraffin and sectioned at $5 \mu \mathrm{m}$. Slides were rehydrated and stained with standard hematoxylin and eosin (H\&E) and Alcian-blue periodic acid Schiff (AB-PAS) stain. Morphology was assessed by imaging five regions under each condition with an Axioskop (Zeiss) wide-field microscope and analyzing the images using AxioVision 4 software. 


\section{$\underline{\text { RNA interference and qRT-PCR }}$}

Primary bronchial or nasal epithelial cells were treated with $5 \mathrm{mM}$ EDTA for $10-20 \mathrm{~min}$ at $37^{\circ} \mathrm{C}$ to improve access to coxsackie adenovirus receptors on the lateral membrane. Virus particles were added together with vehicle $(0.1 \% \mathrm{DMSO})$ or $10 \mathrm{ng} \mathrm{m}^{-1} \mathrm{IL}-4$ on the basolateral side of air-liquid interface cultures for $48 \mathrm{~h}$ (estimated multiplicity of infection $\sim 150$ ). Cells were then rinsed with fresh medium and used for functional studies. Total RNA was isolated from ALI cultures of primary nasal and bronchial epithelial cells using the Qiagen RNeasy Miniprep Kit according to the manufacturer's instructions.

First-strand cDNA for real-time PCR was prepared using $1 \mu \mathrm{g}$ of total RNA and SuperScript VILO MasterMix (Invitrogen). CFTR, SLC26A4 and SLC26A9 mRNA levels were assessed by quantitative real-time PCR (qRT-PCR) using Taqman primers (Life technologies; Assay ID: CFTR: Hs00357011_m1; SLC26A4: Hs01070620_m1; SLC26A9: Hs00369451_m1). Reactions were analyzed using the Quant Studio ${ }^{\text {TM }} 7$ Flex Real-Time PCR system (Life Technologies) and the "Fast" program: $95^{\circ} \mathrm{C}$ for $20 \mathrm{~s}$, followed by 40 cycles of $95^{\circ} \mathrm{C}$ for $1 \mathrm{~s}$ and $60^{\circ} \mathrm{C}$ for $20 \mathrm{~s}$. Data were normalized to GAPDH.

\section{$\underline{\text { Immunostaining pendrin and CFTR in bronchial sections and primary cultures }}$}

To image single isolated primary cells, ALI cultures were gently scraped into PBS and centrifuged onto a glass slide at using a Cytospin4 (450 rpm for $5 \mathrm{~min}$, Thermo Scientific, Cheshire, UK). After fixation in 10\% neutral buffered formalin (15 min at RT), samples were rinsed with PBS (3 x 5 min), permeabilized using 1\% Triton X-100, and blocked with 2\% BSA in PBS for $1.5 \mathrm{~h}$ at RT Tissue sections ( $5 \mu \mathrm{m}$ thick) were mounted on microscope slides, de-paraffinized in xylene baths 
( $3 \times 5$ min each), and rehydrated in alcohol baths $(95 \%, 95 \%, 70 \% ; 5$ min each) followed by two 5 min rinses in $\mathrm{ddH}_{2} \mathrm{O}$ and equilibration in PBS. Sections were permeabilized using $0.5 \%$ Triton $\mathrm{X}-100$ and blocked for $1 \mathrm{~h}$ with $2 \%$ bovine serum albumin (BSA) in PBS at room temperature (RT). Primary cells cultured on collagen-coated Transwell ${ }^{\mathrm{TM}}$ inserts were incubated with PBS on the apical side for $15 \mathrm{~min}$ at $37{ }^{\circ} \mathrm{C}$ in a $5 \% \mathrm{CO}_{2}$ incubator, rinsed three times to remove apical mucus secretions and then immunostained. To image single isolated primary cells, ALI cultures were washed three times with PBS at RT and gently scraped from the inserts into PBS and centrifuged onto a glass slide at using a Cytospin4 (450 rpm for $5 \mathrm{~min}$, Thermo Scientific, Cheshire, UK). After fixation in 10\% neutral buffered formalin (15 min at RT), samples were rinsed with PBS (3 x 5 min), permeabilized using 1\% Triton X-100, and blocked with 2\% BSA in PBS for 1.5 $\mathrm{h}$ at RT.

\section{$\underline{\text { Intracellular } \mathrm{pH} \text { measurements }}$}

Any mucus on the apical surface was removed by 5-10 min incubation with PBS containing Nacetyl-1-Cysteine $\left(1 \mathrm{mg} \mathrm{ml}^{-1}\right)$ at $37^{\circ} \mathrm{C}$ and the cells were rinsed three times with PBS at RT. Then confluent cell monolayers were washed for $30 \mathrm{~min}$ in $\mathrm{HCO}_{3}^{-}$-buffered solution and incubated with the pH-sensitive dye BCECF-AM (2',7'-bis-(2-carboxyethyl)- 5(6)-carboxyfluorescein acetoxymethyl ester) $\left(5 \mu \mathrm{mol} 1^{-1}\right)$ in $\mathrm{HCO}_{3}^{-}$-buffered $5 \% \mathrm{CO}_{2}$ solution at $37^{\circ} \mathrm{C}$ for $\geq 45 \mathrm{~min}$. Cells were then rinsed again and mounted in a chamber that allowed independent apical and basolateral perfusion. Experiments were carried out at $37^{\circ} \mathrm{C}$ using a thermostatically controlled platform (FC5, Live Cell Instr., Seoul Korea). Flow to both surfaces was maintained at $1.5 \mathrm{ml} \mathrm{min}{ }^{-1}$ using a four-channel peristaltic pump (205S, Watson Marlow, Wilmington MA). The normal $\mathrm{HCO}_{3}{ }^{-}$ solution contained (mmol 1-1): $116 \mathrm{NaCl}, 25 \mathrm{Na} \mathrm{HCO}_{3}^{-}, 5 \mathrm{KCl}, 1 \mathrm{CaCl}_{2}, 1 \mathrm{MgSO}_{4}, 2.8 \mathrm{NaHEPES}^{-}$ 
2.2 HEPES and $10 \mathrm{D}$-glucose and $\mathrm{Cl}^{-}$-free solution contained 116 sodium gluconate, $25 \mathrm{Na} \mathrm{HCO}_{3}^{-}$, 5 potassium gluconate, 4 calcium gluconate, $1 \mathrm{MgSO}_{4}, 2.8 \mathrm{NaHEPES}, 2.2$ HEPES and 10 Dglucose. All solutions were adjusted to $\mathrm{pH} 7.4$ by bubbling with a $95 \% \mathrm{O}_{2}, 5 \% \mathrm{CO}_{2}$ mixture at 37 ${ }^{\circ} \mathrm{C}$.

Intracellular BCECF was excited alternately at 440 and $490 \mathrm{~nm}$ (1 s each wavelength) every $5 \mathrm{~s}$. The signal was not perfectly uniform therefore fluorescence intensities were measured in at least 10 regions of interest (ROIs) using Easy Ratio Pro software (Horiba Sci. Mississauga, ON). Unbiased sampling of $\mathrm{pH}_{\mathrm{i}}$ was performed by measuring fluorescence in five ROIs per field; one at the outer edge of each of four quadrants and one near the center. These ROIs covered $\sim 2 / 3$ of the field of view using a $40 \times$ objective. Fluorescence intensities in several ROIs were averaged to obtain one measurement from each experiment. Fluorescence ratios $(F 490 / F 440)$ were recorded and displayed continuously. To calculate $\mathrm{pH}_{\mathrm{i}}$, the $F 490 / F 440$ was calibrated using high- $\mathrm{K}^{+}$nigericin solution that contained $\left(\mathrm{mmol} \mathrm{l}^{-1}\right): 140 \mathrm{KCl}, 1 \mathrm{CaCl}_{2}, 1 \mathrm{MgSO}_{4}, 20 \mathrm{HEPES}$ and $20 \mu \mathrm{mol}$ $1^{-1}$ nigericin, and was adjusted to different $\mathrm{pH}$ values. Graphs and statistical analyses were performed using Microsoft Excel and Prism 5 software.

\section{Measurement of ASL height}

ASL height was measured using an LSM-780 confocal microscope (Zeiss, Jena, Germany) equipped with a multiline Argon laser $(488 \mathrm{~nm}, 561 \mathrm{~nm})$ after transduction with adenovirus particles directing expression of scrambled (Scr) or pendrin (PDS) shRNA. Cells were exposed to amiloride $(10 \mu \mathrm{M})$ alone, or together with forskolin $(10 \mu \mathrm{M})$ or forskolin + IL-4 $(10 \mathrm{ng} / \mathrm{ml})$ for 48 $\mathrm{h}$ before experiments. To visualize the ASL, BCECF-dextran was delivered onto the apical surface 
in perfluorocarbon FC-72 that was allowed to evaporate for 1-2 $\mathrm{h}$ before imaging the surface liquid. XZ scanning images (1.06 $\mu \mathrm{m}$ apart, 40 - 100 images) were collected from 4 - 6 different regions at $\sim 0.88 \mathrm{~mm}$ from the edge of the Transwell to determine fluid height.

\section{$\underline{\text { Patch clamp }}$}

Transfections were performed using Gene Juice (Millipore) according to the manufacturer's instructions. Cells were cultured at $37^{\circ} \mathrm{C}$ in $5 \% \mathrm{CO}_{2}$. Voltage-clamp signals were recorded with an analog/digital interface (Digidata 1440; Axon Instruments, Inc., Burlingame, CA) and analyzed using pCLAMP version 10 (Axon Instruments). The external bath solution contained (in mM): $145 \mathrm{NaCl}, 4 \mathrm{CsCl}, 1 \mathrm{CaCl}_{2}, 1 \mathrm{MgCl}_{2}, 10$ glucose, and 10 tetradecyl sulfate (TES) titrated with

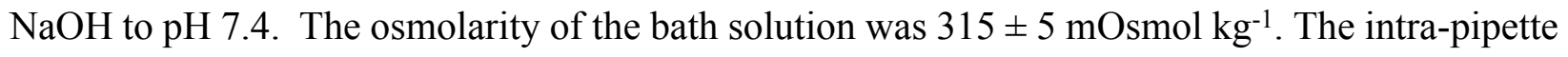
solution contained (in mM): 113 L-aspartic acid, $113 \mathrm{CsOH}, 27 \mathrm{CsCl}, 1 \mathrm{NaCl}, 1 \mathrm{MgCl}_{2}, 1$ ethyleneglycoltetraacetic acid, $1 \mathrm{TES}$, and $3 \mathrm{MgATP}$ titrated to $\mathrm{pH} 7.2$ with $\mathrm{CsOH}$. Osmolality of the pipette solution was $285 \pm 5 \mathrm{mOsmol} \mathrm{kg} \mathrm{k}^{-1}$. Patch clamp experiments were performed at room temperature $\left(20-25^{\circ} \mathrm{C}\right)$.

\section{RESULTS (SUPPLEMENTARY)}

Supplementary Figure 1 Comparison of pendrin mRNA expression in non-CF bronchial epithelia after pendrin knockdown using shRNA adenovirus.

Supplementary Figure 2 CFTR-dependent intracellular alkalinization response $(\Delta \mathrm{pHi})$ after upregulation of pendrin by IL-4.

Supplementary Figure 3 Upregulation of CFTR-dependent short-circuit current $\left(I_{s c}\right)$ by IL-4 in well-differentiated primary nasal and bronchial epithelial cells. 
Supplementary Table 1 Gene-specific primers used for real-time qPCR using Taqman Gene Expression assay

\section{DISCUSSION (SUPPLEMENTARY)}

\section{Regulation of pendrin and CFTR function}

Reciprocal CFTR - pendrin regulation was observed in both nasal and bronchial primary cells. Forskolin activation of CFTR increased the $\Delta \mathrm{pH}_{\mathrm{i}}$ induced by apical Cl--free solution, but only after pendrin expression had been elevated by IL-4. Thus, electrical coupling between $\mathrm{HCO}_{3}{ }^{-}$and $\mathrm{Cl}^{-}$ flows is not detectable during CFTR activation and the $\Delta \mathrm{pH}_{\mathrm{i}}$ during challenge with apical $\mathrm{Cl}^{-}$-free solution is mainly due to electroneutral $\mathrm{HCO}_{3}^{-}$entry through pendrin. Our finding that purinoceptor-activation of anion conductance also did not induce or increase $\Delta \mathrm{pH}_{\mathrm{i}}$ after IL-4 pretreatment further strengthens the argument against electrical coupling between anions. IL-4 induced pendrin expression and increased bicarbonate and fluid secretion across nasal cells, and both these effects were suppressed by pendrin shRNA, which reduced pendrin mRNA levels by $\sim 50 \%$ (Supplementary Figure 1). This indicates that pendrin both mediates $\mathrm{HCO}_{3}^{-}$flux and enhances $\mathrm{Cl}^{-}$secretion through CFTR, with the latter driving most fluid transport. Purinoceptorstimulation of $\mathrm{Ca}^{2+}$-activated $\mathrm{Cl}^{-}$channels was also increased by IL-4 but was unaffected by pendrin shRNA, as expected when TMEM16A expression is elevated (14, 20, 27, 35). Reciprocal pendrin-CFTR regulation may result from a direct protein-protein interaction resembling those proposed for SLC26A3, SLC26A6 and SLC26A9 (28-30, 54-56). The present work provides direct evidence for pendrin-mediated regulation of CFTR in primary HBE cells and in non-epithelial BHK cells that stably express heterologous CFTR. Forskolin stimulation of CFTR-mediated whole cell $\mathrm{Cl}^{-}$currents was strongly enhanced in BHK cells by the co-expression of pendrin, and this was 
observed when cells were bathed with nominally bicarbonate-free solution. Finally, activation of CFTR would lower intracellular $\left[\mathrm{Cl}^{-}\right]$and this may enhance CFTR-mediated $\mathrm{HCO}_{3}{ }^{-}$secretion through a mole fraction effect on permeation (57) or an increase in $\mathrm{P}_{\mathrm{HCO}-} / \mathrm{P}_{\mathrm{Cl}}$ due to WNK1OSR1/SPAK signaling, which is activated by low intracellular $\mathrm{Cl}^{-}(58)$. 


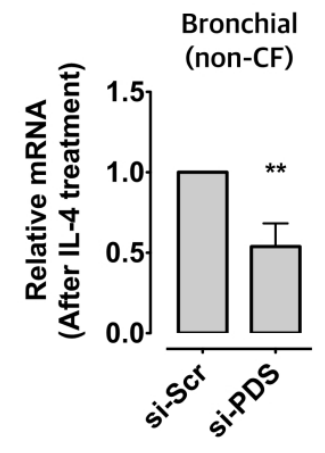

Comparison of pendrin mRNA expression in non-CF bronchial epithelia after pendrin knockdown using siRNA adenovirus. mRNA levels were measured using QRT-PCR and normalized to GAPDH transcripts. Note the $50 \%$ reduction in pendrin expression in PDS knockdown cells. (Mean \pm s.e., $n=5 ;{ }^{* *} \mathrm{p}=0.002$ )

\section{Supplementary Figure 1}

Supplementary Figure 1 Comparison of pendrin mRNA expression in non-CF bronchial epithelia after pendrin knockdown using shRNA adenovirus.

$215 \times 276 \mathrm{~mm}(300 \times 300 \mathrm{DPI})$ 


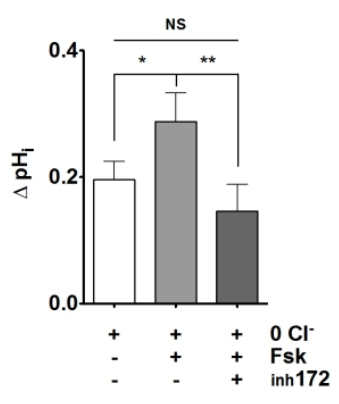

CFTR-dependent intracellular alkalinization response $(\Delta \mathrm{pHi})$ after upregulation of pendrin by IL-4. $\Delta \mathrm{pHi}$ was measured during exposure to apical solution in which $\mathrm{Cl}^{-}$was replaced with gluconate. Note that alkalinization was enhanced by CFTR activation using forskolin and reduced by subsequent exposure to the CFTR inhibitor CFTR $_{\text {inh }}-172$.

\section{Supplementary Figure 2}

Supplementary Figure 2 CFTR-dependent intracellular alkalinization response $(\Delta \mathrm{pHi})$ after upregulation of pendrin by IL-4.

$215 \times 276 \mathrm{~mm}(300 \times 300 \mathrm{DPI})$ 

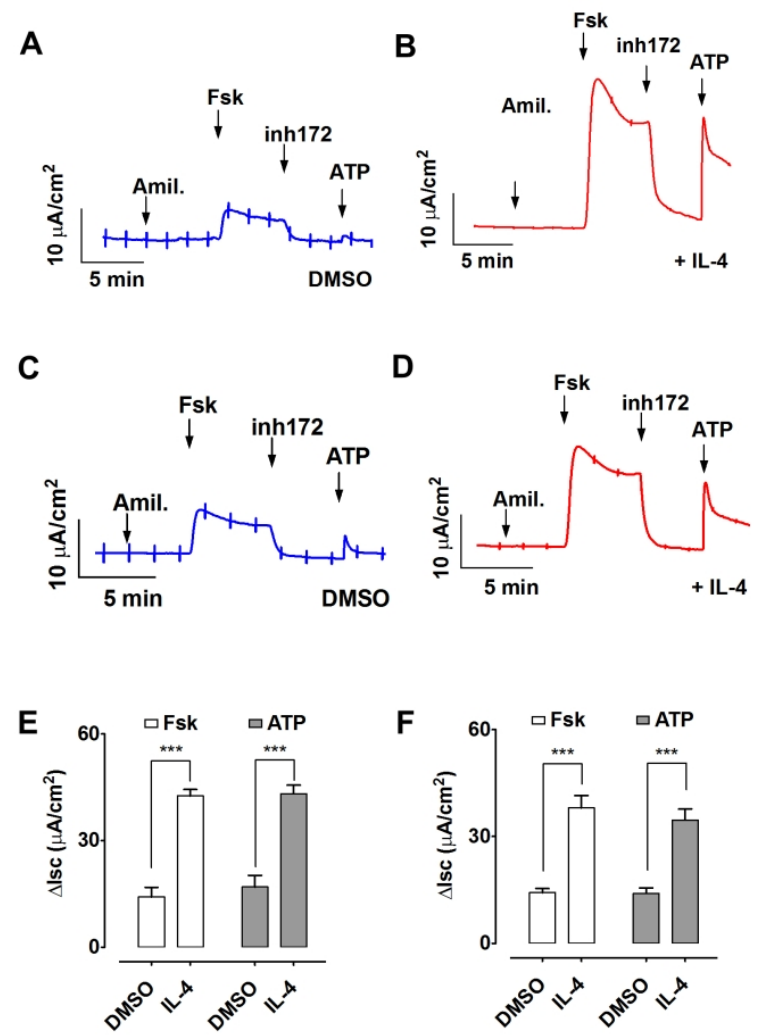

\begin{abstract}
Upregulation of CFTR-dependent short-circuit current $\left(\mathrm{I}_{\mathrm{sc}}\right)$ by IL-4 in well-differentiated primary nasal and bronchial epithelial cells. $(A)$ Effect of sequential exposure to amiloride (Amil.), forskolin (Fsk), CFTR inhibitor (CFTR $_{\text {inh }}-172$ ), and ATP (purinoceptor agonist) on $\mathrm{I}_{\mathrm{sc}}$ across nasal cells pretreated with vehicle $(0.1 \%$ DMSO) for 2 days. $(B)$ same conditions as $(A)$ except cells were pretreated with IL-4 $(10 \mathrm{ng} / \mathrm{ml})$ for 2 days. Note robust currents mediated by CFTR and $\mathrm{Ca}^{2+}$-activated chloride channels. $(C, D)$ Bronchial epithelial cells under the same conditions as in $(A)$ and $(B)$, respectively. (E) Summary of forskolin- and ATP-stimulated currents across nasal epithelial cells pretreated with vehicle or IL-4 (Mean \pm s.e., $n=9-12$, ${ }^{* \star} p<0.001$ ). $(F)$ Summary of $\mathrm{I}_{\mathrm{sc}}$ responses across bronchial epithelial cells under same conditions as in $(E)$. Mean \pm s.e., $n=15,{ }^{* * \star} p<0.001$.
\end{abstract}

\title{
Supplementary Figure 3
}

Supplementary Figure 3 Upregulation of CFTR-dependent short-circuit current (Isc) by IL-4 in welldifferentiated primary nasal and bronchial epithelial cells.

$$
215 \times 276 \mathrm{~mm}(300 \times 300 \mathrm{DPI})
$$


Gene-specific primers used for real-time qPCR with the Taqman Gene Expression assay

\begin{tabular}{|c|c|c|c|}
\hline Gene & Assay ID number & Accession number & $\begin{array}{c}\text { Amplicon length } \\
\text { (bp) }\end{array}$ \\
\hline CFTR & Hs00357011_m1 & NM_000492.3 & 93 \\
\hline SLC26A4 & Hs01070620_m1 & NM_000441.1 & 89 \\
\hline SLC26A9 & Hs00369451_m1 & NM_134325.2 & 67 \\
\hline
\end{tabular}

https://www.thermofisher.com/order/genome-database/

https://www.ncbi.nlm.nih.gov/nuccore/NM 000492.3

\section{Supplementary Table 1}

Supplementary Table 1 Gene-specific primers used for real-time qPCR using Taqman Gene Expression assay $215 \times 276 \mathrm{~mm}(300 \times 300 \mathrm{DPI})$ 